\title{
COMMENTS
}

\section{Prosecutors' Deterrence Appeals in State Criminal Trials}

The varieties of rhetorical excess employed by state prosecutors in closing argument to juries are legion. ${ }^{1}$ In a few instances through constitutional strictures, and more frequently through an evolved consensus of state case law, certain forms of prosecutorial rhetoric are condemned in criminal trials. Prosecutors may not, for example, comment on the failure of the defendant to testify, ${ }^{2}$ make overt appeals to racial prejudice, ${ }^{3}$ express their personal belief in a defendant's guilt, ${ }^{4}$ engage in personalized arguments to individual jurors, ${ }^{5}$ or assert the truth of facts that have not been presented in evidence. ${ }^{6}$ This comment explores another classic technique of jury persuasion, the use of deterrence rhetoric by prosecutors in closing summation, and concludes that it, too, should be prohibited. In using deterrence rhetoric, the prosecutor argues that a defendant should be convicted in order to deter him and others of like mind from committing crimes in the future. Such rhetoric may be specific, focusing on the future conduct of the individual on trial, or

1 Prosecutors' rhetoric has been discussed a number of times. See Alschuler, Courtroom Misconduct by Prosecutors and Trial Judges, 50 TEx. L. REv. 629 (1972); Crump, The Function and Limits of Prosecution Jury Argument, 28 Sw. L. REv. 505 (1974); Singer, Forensic Misconduct by Federal Prosecutors-and How It Grew, 20 AlA. L. Rkv. 227 (1968); Vess, Walking a Tightrope: A Survey of Limitations on the Prosecutor's Closing Argument, 64 J. CRm. L. \& Crmmology 22 (1973); Note, The Nature and Consequences of Forensic Misconduct in the Prosecution of a Criminal Case, 54 Colum. L. Rev. 946 (1954).

2 Griffin v. California, 380 U.S. 609 (1965). See generally J. Strin, Closing ARguMRNT-THE ART AND THE LAW \& 44 (1978).

See text and notes at notes 100-101 infra.

- See J. Stzin, supra note 2, § 70; Annot., 41 A.L.R. Fed. 10 (1979); Annot., 88 A.L.R. 3d 449 (1978). See also ABA Codz of Profzssional Responsibility DR 7-106(c) (4) (counsel are not to assert personal opinions about the guilt of an accused).

- See J. STanN, supra note $2, \S 80$.

- See Vess, supra note 1, at 27-31. There is also consensus among the states that prosecutors may not suggest that additional incriminating evidence has been suppressed, discuss the possibility of pardon or parole, or argue that jurors' mistakes can be corrected on appeal. See generally J. STEn, supra note 2, §§ 76, 78; Alschuler, supra note 1, at 634 . 
general, pointing to the asserted causal relationship between the jury's verdict and the behavior of the criminal element at large. It appeals to jurors by "making predictions of the consequences of ... [their] verdict," suggesting "that the people look to them for protection against crime, and . . . illustrat[ing] the effect of their verdict on the community or society generally with respect to obedience to, and enforcement of, the law."s

This comment focuses exclusively on the use of deterrence appeals in the evaluation of an individual's guilt or innocence ${ }^{\ominus}$ in state criminal trials. ${ }^{10}$ Because of the current strict barriers to federal habeas corpus review of prosecutorial excesses in state

7 ABa Project on Standards for Criminal Justice, Standards Relating to the Prosecution Function and the Defense Function § 5.8(d), at 126 (Approved Draft 1971) [hereinafter cited as ABA STANDARDs].

s 23A C.J.S. Criminal Law § 1107 (1961) (footnotes omitted).

- Although one could perhaps make a case for the propriety of deterrence appeals in the sentencing context, this comment discusses the use of such rhetoric only in the determination of an individual's guilt or innocence.

In jurisdictions with a bifurcated system of criminal procedure, the permissible limits of prosecutors' deterrence appeals at the sentencing stage are the subject of increasing debate. Compare Starvaggi v. State, 593 S.W.2d 323, 328 (Tex. Crim. App. 1979) (proper for prosecutor in arguing for imposition of the death sentence to warn jurors that "I hope he doesn't come knocking on one of your doors at eight o'clock in the evening"), cert. denied, $100 \mathrm{~S}$. Ct. 3050 (1980) and Stone v. State, 574 S.W.2d 85, 90 (Tex. Crim. App. 1978) (proper to urge jurors to "think about the other children that live in this community that are subjected to this kind of conduct [rape]") with Brown v. Estelle, 468 F. Supp. 42 (N.D. Tex. 1978), aff'd per curiam, 591 F.2d 1207 (5th Cir. 1979), a habeas corpus proceeding in which the prosecutor at the sentencing stage of the trial engaged in "persistent and pronounced" misconduct in his argument, $i d$. at 49 . According to the District Court, appeals such as "What side are you on? Are you going to coddle them or going to punish them?" "urged the jury to impose a sentence on petitioner not only for what he had done but for what other thieves and criminals were doing," $i d$. at 48 , and in combination with other violations required a new trial. See also Vaughn v. State, 126 Ga. App. 252, 190 S.E.2d 609 (1972); Sier v. State, 517 P.2d 803, 805 (Okla. Crim. App. 1973).

${ }^{10}$ Standards of argument traditionally have been stricter in the federal courts; the fearless administration doctrine, on which this comment focuses, is a creature unique to state case law. There is as yet no uniform federal standard to govern prosecutorial deterrence rhetoric, however. Although some opinions have condemned deterrence appeals in the strongest terms, see, e.g., United States v. Barker, 553 F.2d 1013, 1025 (6th Cir. 1977) (conviction reversed because of prosecutor's argument that "if you can't take this evidence and find these defendants guilty on this evidence then we might as well open all the banks and say, 'Come on and get the money, boys, because we'll never be able to convict them' "), federal courts occasionally hold that specific appeals are within the bounds of permissible advocacy, see, e.g., United States v. Stead, 422 F.2d 183, 184 (8th Cir.) (permissible to ask jury "for the good of the community that you represent, rid ourselves of these burglars, sneak thieves in the night. . . and find him guilty as charged"), cert. denied, 397 U.S. 1080, 398 U.S. 966 (1970). The usual practice, though, has been to condemn such appeals while employing the harmless error doctrine to avoid reversal and retrial. See note 166 infra. 
courts, ${ }^{11}$ the states have been free to develop their own jurisprudence with regard to deterrence rhetoric. As a result, one encounters a broad spectrum of responses. At one end of this spectrum, many states use the "fearless administration of the law" and analogous doctrines as a basis for permitting nearly all forms of deterrence rhetoric. ${ }^{12}$ At the other end, a few states explicitly forbid deterrence appeals, however mildly worded, as inherently prejudicial. $^{13}$ The large number of states between these positions are more difficult to classify. Some accept the fearless administration doctrine but employ categorical distinctions to discourage certain forms of deterrence appeals; ${ }^{14}$ others attempt to prevent "highly prejudicial" deterrence appeals,; ${ }^{15}$ and many use the harmless error doctrine to avoid deciding the propriety of this rhetoric. ${ }^{16}$

This comment first examines this spectrum of state responses. It next considers the historical, evidentiary, and functional justifications for permitting deterrence rhetoric at the conviction stage of trial, and finds them all wanting. Finally, the comment discusses

11 The structure for federal review of state prosecutorial argument is governed by Donnelly v. DeChristoforo, 416 U.S. 637 (1974). In that case Justice Rehnquist elaborated a formidable array of requirements that have effectively precluded federal control over most forms of rhetoric. First, the remarks must violate a specific right granted by a specific provision of the Bill of Rights. Second, appellants must demonstrate that the remarks had an actual prejudicial impact; federal courts cannot engage in "hypothetical analysis" of the effect of the remarks on the jury. Third, the comments must not be "isolated passages" and "but one moment" in an extended proceeding. Finally, the comments must meet a standard of "egregious misconduct" necessary to amount to a denial of constitutional due process. Id. at 642-46.

For the effect of Donnelly on federal control of deterrence rhetoric in state trials, see Houston v. Estelle, 569 F.2d 372, 384 (5th Cir. 1978) ("The constitutional frontier stands very far indeed from the core of good prosecutorial practice . . . ."); Perry v. Mulligan, 399 F. Supp. 1285 (D.N.J. 1975), rev'd sub. nom. United States ex rel. Perry v. Mulligan, 544 F.2d 674 (3d Cir. 1976), cert. denied, 430 U.S. 972 (1977). One district court, applying Donnelly, has explicitly held that "there is no constitutional prohibition against reference during argument to the deterrence function of the criminal law." Heffelfinger v. Thompson, 444 F. Supp. 309, 310 (E.D. Tenn. 1977) (permitting, although not "vouch[ing] for the propriety" of, the argument that "I want to protect your daughter, your granddaughter, and the daughters and granddaughters all over this United States. . . . How much of an example do you want to set to other people who might be tempted to do this . . . .").

12 Most notable are Alabama, Georgia, Illinois, Missouri, Oklahoma, and Texas. See text and notes at notes 17-46 infra.

13 Most notable are Michigan, Pennsylvania and Virginia. See text and notes at notes 58-65 infra.

14 See text and notes at notes 49-51 infra.

1s See text and notes at notes 52-57 infra.

16 For a discussion of the impact of harmless error on this definitional process, see text and note at note 167 infra. 
the procedural considerations involved in ensuring the effective prohibition of deterrence rhetoric.

\section{The Spectrum of Deterrence Rhetoric in State Courts}

\section{A. The Fearless Administration Doctrine in Practice}

Many courts sanction deterrence rhetoric under the theory that prosecutors should be allowed to exhort jurors to a fearless administration of the law. ${ }^{17}$ This doctrine enables prosecutors to employ several effective psychological stratagems in closing argument. One of the most common deterrence appeals stresses the positive results of conviction, focusing on the ever-escalating crime wave and the resultant deterioration of life in the jurors' community. ${ }^{18}$ The prosecutor seeks to transform the trial process into something like a plebiscite on criminals in the community, demanding to know "what are we gonna do about them"19 and informing the jury that "it's your turn to stand up and be counted."20 Because of their "unique position,"21 the prosecutor

17 E.g., People v. Hairston, 46 Ill. 2d 348, 375, 263 N.E.2d 840, 856 (1970) ("it is entirely proper for the prosecutor to dwell upon the evils of crime and to urge the fearless administration of the law"), cert. denied, 402 U.S. 972 (1971). The phraseology employed varies from state to state. See, e.g., State v. Jaramillo, 110 Ariz. 481, 483-84, 520 P.2d 1105, 110708 (1974) (prosecutor may "urge the jury to do its duty and uphold the law, and . . . draw inferences from conditions resulting from the failure to uphold the law"); State v. Gordon, 499 S.W.2d 512, 515 (Mo. 1973) ("prosecution has a right to call attention to the prevalence of crime in a community and to argue that a defendant on trial should be convicted in order that others of like mind might be deterred from criminal activity"); State v. Crawford, 478 S.W.2d 314, 320 (Mo. 1972) ("permissible call[s] for law enforcement and discouragement of this type of crime"); Holloway v. State, 525 S.W.2d 165, 170 (Tex. Crim. App. 1975) (prosecutors may make "a proper plea for law enforcement").

${ }^{18}$ See Embrey v. State, 283 Ala. 110, 118, 214 So. 2d 567, 575 (1968) ("We all know the crime rate is rising and rising and rising . . . . You have got to determine whether or not these juries are going to stop these robberies from going on."); State v. Moore, 112 Ariz. 272, 274, 540 P.2d 1252, 1255 (1975) ("We have all heard about the rising crime rate throughout the country. We have heard about the rise in violence. We have read about it. We are sick of it."); People v. Ivery, 72 Ml. App. 3d 158, 161, 390 N.E.2d 608, 611 (1979) ("Good God, people are getting killed. People are being robbed . . . . And we have had it [crime] here in this jury .....").

19 Jones v. State, 555 P.2d 1061, 1066 (Okla. Crim. App. 1976) ("[W] do about these senseless killings, these robberies-execution-type killings. . . . And you have got a chance to do something about it.").

20 Smith v. State, 258 Ind. 594, 601, 283 N.E.2d 365, 369 (1972) ("probably now, more than ever more, you are going to have to come to the spot where it's your turn to stand up and be counted").

${ }^{21}$ People v. Griggs, $51 \mathrm{ml}$. App. 3d 224, 227, 366 N.E.2d 581, 583 (1977) (jury was in a "unique position to be able to do something" about increasing robberies). 
tells jurors that "you alone control this problem," never have a better opportunity to speak out on this matter."2s They are urged to let "the word go out through this jury" ${ }^{24}$ to the accused "and everybody like him out there"2s that citizens will "do something about it"28 and "teach them a lesson."27

Another strain of deterrence rhetoric stresses the consequences that will ensue if the jurors do not convict the defendant. Jurors are warned that by acquitting a defendant they will be consenting to his criminality, and accordingly will be responsible for future lawlessness. ${ }^{28}$ Criminals "are out there and they are considering the odds," criminal activity, grant a "license to kill,"si "open up the floodgates for [criminal] activity,"s2 "open . . . the door to rape"ss and "tell [robbers] to come on in boy." ${ }^{34}$

${ }^{22}$ Fausett v. State, 468 S.W.2d 92, 94 (Tex. Crim. App. 1971) ("You, and you alone control this [drug] problem. . . . [I]t is up to you to decide whether you want it in your community.").

${ }^{23}$ State v. Swenson, 551 S.W.2d 917, 920 (Mo. Ct. App. 1977) ("I want the word to go out through this jury, and you'll never have a better opportunity to speak out on this matter, that if any one ever does this in this community they can know what to expect. . . .").

24 Id. See also Hamilton v. State, 43 Ala. App. 192, 197, 186 So. 2d 108, 113 (1965) ("[s]end word out to everyone").

${ }_{25}$ People v. Jackson, 19 Ill. App. 3d 689, 695, 312 N.E.2d 405, 409 (1974).

18 Richardson v. State, 354 So. 2d 1193, 1199 (Ala. Crim. App. 1978) ("If you want the streets of the State of Alabama to be safe, now is the time for you to do something about it."). See also State v. Whitlock, 598 S.W.2d 521, 522 (Mo. Ct. App. 1980) (violence in the schools, and jurors' "opportunity to do something about it"); State v. Woodward, 587 S.W.2d 287, 291 (Mo. Ct. App. 1979) (jury has to "do something" about drug sales); Aracha v. State, 495 S.W.2d 957, 959 (Tex. Crim. App. 1973) ("do something" about "dope pushers").

${ }_{27}$ Dabbs v. State, 507 S.W.2d 567, 570 (Tex. Crim. App. 1974) (possession of marijuana).

${ }^{38}$ Fletcher v. State, 52 Ala. App. 303, 307, 291 So. 2d 757, 760 (1973) (acquittal constitutes consent to criminal behavior); People v. Benedik, 56 Il. 2d 306, 310-11, 307 N.E.2d 382, 385 (1974).

20 Cook v. State, 369 So. 2d 1251, 1254 (Ala. 1979).

so State v. Rodriguez, 484 S.W.2d 203, 207 (Mo. 1972) (proper for prosecutor to conclude: "So an acquittal today will justify resisting arrest for any charge, allow striking of an officer, and may set a course of conduct that might open up the floodgates for an activity-for a summer of activity along this line, or any time along this line.").

s1 Cook v. State, 369 So. 2d 1251, 1254 (Ala. 1979).

${ }_{32}$ State v. Rodriguez, 484 S.W.2d 203, 207 (Mo. 1972).

${ }^{33}$ Bowman v. State, 446 S.W.2d 320, 320 (Tex. Crim. App. 1969).

s4 Hamilton v. Commonwealth, 401 S.W.2d 80, 87 (Ky. 1966), cert. denied, 385 U.S. 1014 (1967); accord, Hill v. State, 253 Ark. 512, 530-31, 487 S.W.2d 624, 635-36 (1972) (if defendant is acquitted, "you can bet your bottom dollar that every loaning institution and every store in Howard County, Arkansas, is in trouble from now on"). See also State v. Cole, 588 S.W.2d 94, 100 (Mo. Ct. App. 1979) ("Think for a minute what a verdict of Manslaugh- 
One particularly inflammatory variant of this deterrence technique seeks to implant in jurors' minds the fear that acquittal of the defendant and the resultant license granted to others will endanger their own safety or that of their families. Most jurisdictions recognize that such appeals destroy the impartiality of the trial and invite verdicts based on "visceral and unreasoned responses." 35 Several states that follow the fearless administration doctrine, however, sanction demagogic appeals, such as that acquittals of rape defendants will constitute "an invitation . . . that they should come to your neighborhood when your daughter goes out on a date and your wife has to go to the store."38 Prosecutors may argue that unless the jury convicts, "the next time you or your loved ones is [sic] held up, kidnapped, robbed, beaten, there'll be no conviction of the assailant."3z In considering the defendant's guilt, the prosecutor suggests, jurors should "picture [themselves] witnessing the rape of one of [their] loved ones." 38

Still another stratagem is to warn jurors of future criminal behavior by the defendant himself. Assertions that the defendant will leave the courtroom with a "free license"se to "go loose on the streets"40 and resume his lawlessness ${ }^{41}$ are permitted through cursory citation to the fearless administration doctrine.

ter would mean in a case like that to people. They would say, 'Look at this. There isn't anything worse than that. This man is getting off with Manslaughter.' It isn't easy to deter that kind of crime."); Basalda v. State, 481 S.W.2d 851, 854 (Tex. Crim. App. 1972).

ss Commonwealth v. Harvell, $458 \mathrm{~Pa} .406,411,327$ A.2d 27, 30 (1974); see notes 50, 53 infra.

se People v. Madden, 57 Ill. App. 3d 107, 114, 372 N.F.2d 851, 856 (1978). Although the court focused upon the failure of defendant's counsel to object to the statement as waiver of any error, it went on to defend the remarks as proper commentary on the evils of crime.

s7 People v. Van Zile, 48 Ill. App. 3d 972, 984, 363 N.E.2d 429, 438 (1977).

ss Parks v. State, 400 S.W.2d 769, 771 (Tex. Crim. App. 1966). See also People v. Tedder, 83 IIl. App. 3d 874, 404 N.E.2d 437, 445 (1980) (jurors should reflect upon "what's going on in your home now . . . and the people that you've left alone"); State v. Gray, 351 So. 2d 448,460 (La. 1977) ("It's your decision to make as to whether or not we are going to put the animals in the cages to keep them away from doing harm to us and our families or are we going to have to put cages around our houses to keep the animals from coming in.").

s9 People v. Galloway, 74 Ill. App. 3d 624, 628-29, 393 N.E.2d 608, 611 (1979) (prosecutor also stated that Chicago is the way it is because of people like the defendant).

10 People v. Bost, 80 Ill. App. 3d 933, 956, 400 N.E.2d 734, 751 (1980).

${ }^{11}$ See also Cronnon v. Alabama, 587 F.2d 246, 251 (5th Cir. 1979) (habeas corpus appeal from Alabama murder trial: "Well, you turn him loose and whose little girl will be next? Who will be next?"), cert. denied, 440 U.S. 974 (1980); Brand v. Wofford, 230 Ga. 750, 754,199 S.E.2d 231, 234 (1973) ("This boy is going to take these nembutals and sell to yours and my kids for a dollar apiece. If you want to turn him loose to do this, let him do it."); People v. Johnson, 73 Il. App. 3d 431, 435-46, 392 N.E.2d 587, 591 (1979) (acquittal will give defendant "a license to go out there and stop kids on their way to school . . . [ [M]aybe 
A final appeal sanctioned by the fearless administration doctrine focuses the jurors' attention on their role in the law enforcement process and on their "duty" to convict. Prosecutors argue that jurors will not be doing their duty "if they turn every man loose simply because you are afraid of convicting an innocent man."42 Jurors are told that they "must support"4s the efforts of law enforcement officials and that because they are the crucial "last link," failure to convict will undermine the police and the judicial system. ${ }^{45}$ To avoid this chaos, jurors are implored to return a guilty verdict "that your friends and neighbors can be proud of."16

one day you may read in the paper . . . someone was shot on the street and a gun was used"; remarks held "within the realm of fair comment"); People v. Taylor, 18 III. App. 3d 367, 373, 309 N.E.2d 642, 647 (1974); State v. Ray, 600 S.W.2d 70, 73 (Mo. Ct. App. 1980) ("If you want this type of man crossing the bridge and coming into our county and raping women in St. Charles County and [sic] let him go free."); State v. Reynolds, 603 P.2d 1223, 1228 (Or. Ct. App. 1979) (prosecutor urged jury not to acquit defendant "[b]ecause the next time it might be one of you at the end of his barrel"); Debolt v. State, 604 S.W.2d 164, 169 (Tex. Crim. App. 1980) ("What I'm mainly concerned with is he is not among the public, living next door to me or you or to anybody else .....").

Unchecked rhetoric focusing on the future criminal actions of the defendant himself would appear to fall within the Donnelly "egregious misconduct" standard, see note 11 supra. There is no valid state interest justifying this demagoguery. Empirical studies repeatedly have demonstrated our "critical incapacity" to predict future criminal behavior by the defendant. N. MorRIs, The FurURE of IMPRISONMRNT 62-73 (1974). The concept of dangerousness as used in sentencing (let alone conviction) has led to "gross injustice" in the application of laws concerning homicide and sexual psychopathy. Id. at 63.

12 State v. Durden, 264 S.C. $86,91,212$ S.E.2d 587, 590 (1975).

43 Terhune v. State, 117 Ga. App. 59, 60, 159 S.E.2d 291, 293 (1967) ("we were proud of our Atlante police and must support them"). For an extreme example of this type of deterrence appeal, see Miller v. North Carolina, 583 F.2d 701, 708 (4th Cir. 1978) (district attorney informed the jury that his law enforcement powers came from God and that to resist those powers was to resist God; conviction reversed because of additional argument inciting race prejudice).

“ Chatman v. State, 509 S.W.2d 868, 869 (Tex. Crim. App. 1974) (jury "is the last link in law enforcement and if it is not carried through, then [we] may as well just forget it. [We] may as well say to heck with trying to get them to trial while they are still fresh. The Police Department might as well say, "Well, why try to risk my life . . . ' "). The "last link" genre of deterrence rhetoric has had a long and colorful history in Texas. See, e.g., Pemberton v. State, 55 Tex. Crim. 464, 468, 117 S.W. 837, 839 (1909) (proper to argue that "[i]f you do not convict the defendant in this case, than [sic] you had as well close the doors of justice, burn up the law books, tear down the courthouse, and let anarchy reign in this country").

is See, e.g., Amerson v. State, 43 Ala. App. 148, 151, 182 So. 2d 901, 904 (1965) ("Think about how hard it is for the law enforcement officers to get out and work and all you hear is, 'Ah, they are shooting folks up in Covington County. They don't do nothing about it up there in court." "); People v. Agosto, 70 Ill. App. 3d 851, 857, 388 N.E.2d 1018, 1023 (1979).

4t Whittington v. State, 580 S.W.2d 845, 847 (Tex. Crim. App. 1979). 


\section{B. The Limits of Deterrence Rhetoric}

Although most states recognize some limits on the use of deterrence rhetoric, they disagree on where to set those limits. Courts in some states permit the virtually unlimited employment of deterrence rhetoric under the fearless administration doctrine. ${ }^{47}$ Only on rare occasions is oratory by prosecutors condemned; ${ }^{\mathbf{8}}$ deterrence rhetoric of the variety outlined above is permitted as a matter of routine.

Some states, although they explicitly accept the fearless administration doctrine, seek to set prophylactic limits on certain forms of deterrence appeals such as predictions of defendants' future criminal acts ${ }^{49}$ and inflammatory evocations of jurors' personal fears. ${ }^{\text {s0 }}$ Case law in these states is rather inconsistent because of an essentially ad hoc approach; tricks of the prosecutorial trade enable prosecutors to couch these appeals in acceptable language, thus rendering the states' formal distinctions meaningless in practice. ${ }^{.1}$

47 Illinois and Texas are leading examples. See Illinois and Texas cases cited notes 1746 supra.

48 E.g., People v. Payton, 72 Ill. App. 2d 240, 249, 218 N.E.2d 518, 522 (1966); Joyner v. State, 436 S.W.2d 141, 144 (Tex. Crim. App. 1969).

49 See, e.g., State v. Heinrich, 492 S.W.2d 109, 115 (Mo. Ct. App. 1973) (if defendant is not convicted, "he's going to hurt somebody"); Lime v. State, 479 P.2d 608, 609 (Okla. Crim. App. 1979) (if defendants not convicted, "there will be somebody else's relative that will be killed by these two men within I will say, a year or two").

so See, e.g., Adams v. State, 229 Ark. 777, 779, 318 S.W.2d 599, 600 (1958) ("Now, gentlemen if you turn this man loose go home and tell your daughters that you made it really hard for them today because you turned a man loose that can run over them and take anything from them he wants to and then come up here and tell [a] cock and bull story and get away with it"); State v. Groves, 295 S.W.2d 169, 173 (Mo. 1956) ("if this defendant ever got the opportunity your daughter could be the next one, or your grandchild or something").

s1 For instance, in Missouri, a prosecutor may not suggest that the defendant himself will commit another crime if acquitted, State v. Heinrich, $492 \mathrm{~S} . W .2 \mathrm{~d} 109,115$ (Mo. Ct. App. 1973), but may argue that "this type of man" will, State v. Ray, 600 S.W.2d 70, 73 (Mo. Ct. App. 1980).

That the prosecutor cannot argue that the jury should convict because their community wants or expects them to has always been a fundamental rule of closing argument. Jackson v. Commonwealth, $301 \mathrm{Ky} .562,566,192 \mathrm{S.W} .2 \mathrm{~d} 480,482$ (1946) (prejudicial to argue that county is watching jurors to see what kind of character they have); Pennington v. State, 171 Tex. Crim. 130, 131-32, 345 S.W.2d 527, 528 (1961) (forbidding argument that the people of the county expect defendant to be put away). See generally Annot., 85 A.L.R.2d 1132 (1962). By avoiding the buzzword "expect," however, prosecutors may bring virtually identical rhetoric within the ambit of the fearless administration doctrine. E.g., Pennington v. Commonwealth, 455 S.W.2d 530, 532-33 (Ky. 1970) (wondering how jurors will feel when they come face-to-face with friends and neighbors); Whittington v. State, 580 S.W.2d 845, 847 (Tex. Crim. App. 1979). 
Appellate courts in other states have not announced an explicit rule about the propriety of deterrence oratory. They have, however, condemned references to defendants' future criminality, ${ }^{\mathbf{6 2}}$ family-safety speeches, ${ }^{63}$ and predictions that unless a particular defendant is convicted it will be impossible to maintain law and order in the jurors' community. ${ }^{\text {s4 }}$ These courts frequently offer as their only reasoning statements such as that the "interest of justice"ss g requires reversal because particular rhetoric "exceeded proper limits"s8 or was "inflammatory" and "highly prejudicial." These conclusory sentiments, with nothing more, fail to give trial judges and prosecutors a sense of what renders an argument "prejudicial." It is impossible to determine from the few appellate opinions in these states whether deterrence appeals are handled at the trial stage on a sliding scale of inflammatory content or are categorically prohibited.

A few states, most notably Michigan, ${ }^{58}$ Pennsylvania, ${ }^{68}$ and

s2 See, e.g., Williams v. State, 68 So. 2d 583, 583 (Fla. 1953) (defendant will kill again); Sims v. State, 371 So. 2d 211, 212 (Fla. Dist. Ct. App. 1979) (if jury acquits they should "shake Alex Sims' hand" and say " '[g]o get another one Alex' "); People v. Slaughter, 28 A.D.2d 1082, 1082, 285 N.Y.S.2d 146, 147 (1967) ("in this time of permission, what we can call an age of license, are you going to extend to the Henry Slaughters of this world the license to strike out and kill, to disrupt their families, to steal, to do any thing that they please because the world is against them, or are you going to call them to task? Are you going to protect, finally here, at this point of the lawsuit, the rights of the community in which you live?").

ss See, e.g., Adams v. State, 192 So. 2d 762, 763 (Fla. 1966) ("I ask you to just think if your wife wasn't there because she had been murdered by a robber . . . [0]r your daughter . . . ." (emphasis omitted)); Barnes v. State, 58 So. 2d 157, 158 (Fla. 1952) ("What if it was your wife or your sister or your daughter that this beast was after . . . ."); State v. Jones, 266 Minn. 523, 524, 124 N.W.2d 727, 727-28 (1963) ("It could be my daughter, it could be your daughter . . . . . [I]t could be my wife, it could be somebody else's wife.").

- See, e.g., Russell v. State, 233 So. 2d 154, 155 (Fla. Dist. Ct. App. 1970) (if people like defendant are not convicted, "we are going to have a breakdown in society and we are going to have people getting stabbed all over Orange County"); People v. Wallason, 62 A.D.2d 1026, 1026, 404 N.Y.S.2d 23, 24 (1978); People v. Moore, 26 A.D.2d 902, 905, 274 N.Y.S.2d 518, 519 (1966) (if jury wants to live in community where crime runs rampant, it should acquit defendant); People v. Gioia, 286 A.D.2d 528, 530, 145 N.Y.S.2d 495, 498 (1955) (acquittal would be "an invitation to every hoodlum and every drug addict and every bum in New York . . . to indulge in robberies").

ss People v. Moore, 26 A.D.2d 902, 902, 274 N.Y.S.2d 518, 519 (1966).

Id.

67 Russell v. State, 233 So. 2d 154, 155 (Fla. Dist. Ct. App. 1970).

se See, e.g., People v. Biondo, 76 Mich. App. 155, 157, 256 N.W.2d 60, 61-62 (1977) (argument in larceny case that business was the "life blood" of Detroit, and "if these businesses, of course, are preyed upon, then they will leave the city, and the city will die" deprived defendant of fair trial); People v. Meir, 67 Mich. App. 534, 536-38, 41 N.W.2d 280, 281-82 (1976) (prosecutor's argument that defendant might sell heroin to jurors' children and that acquittal would condone drug usage was forbidden, and, because judge only mildly 
Virginia ${ }^{60}$ have explicitly rejected the relevance of deterrence considerations in determining a defendant's guilt or innocence. ${ }^{61}$ These states have decided that deterrence rhetoric, however mildly presented, is inherently inflammatory. Failure to make the "important distinction" that "[c]onviction for an offense must be based solely upon evidence of guilt, and not upon considerations of deterrence," is likely to result in "substantial prejudice" to a defendant. 62 These courts find "no justification"63 for deterrence rhetoric, because it tends to invite jurors to make an example of the defendant ${ }^{\beta 4}$ whereas " $[t]$ he issue is not whether the jury approves of crime, but whether the evidence shows the accused is guilty of it under the law."

chastised prosecutor for these remarks, reversal was required); People v. Williams, 65 Mich. App. 753, 755, 238 N.W.2d 186, 187 (1975) (argument that "you have an opportunity to effect [sic] the drug traffic in this city" was "highly prejudicial"); People v. Farrar, 36 Mich. App. 294, 298, 193 N.W.2d 363, 365 (1971) ("The prosecutor may not subtly convert the presumption of innocence into a presumption of guilt by appealing to the jurors to perform a civic duty to support the police.").

B8 See, e.g., Commonwealth v. Cherry, 474 Pa. 295, 305, 378 A.2d 800, 805 (1977) (prosecutor's remarks to jury asking them to tell the people of Philadelphia that "shootings on the street like the wild West" will not be tolerated was an invitation to make an example of defendant and required reversal); Commonwealth v. Harvell, $458 \mathrm{~Pa} .406,411,327 \mathrm{~A} .2 \mathrm{~d} 27$, 30 (1974) (statement that "[p]eople don't want to go out at night . . . it might be one of you next time. It might be you" invited jury to give vent to "visceral and unreasoned responses"). See also Commonwealth v. Anderson, $490 \mathrm{~Pa} .225,415$ A.2d 887 (1980).

Recent opinions at the Superior Court level, however, have said that although, "not approved," deterrence rhetoric will not be condemned if the "cumulative effect" is mild, and that prosecutors may, "within proper limits, argue for law and order." Commonwealth v. Clark, 421 A.2d 374, 378-79 (Pa. Super. Ct. 1980); Commonwealth v. Nesbitt, 419 A.2d 64, 70 (Pa. Super. Ct. 1980) (if defendant acquitted, "[l]et's all go get armed . . . . Bring back Dodge City."). It is not clear whether these cases, which on their face contradict the decisions of the Pennsylvania Supreme Court, are aberrations or initial indicators of a doctrinal shift.

so See Hutchins v. Commonwealth, 255 S.E.2d 459, 460-61 (Va. 1979) (argument in burglary trial asking "[w] $[$ hat message are you going to send out to the people of Franklin County?" was impermissible); Bolton v. Commonwealth, 200 Va. 5, 10, 104 S.E.2d 1, 5 (1958) (impermissible to argue that "[y]ou members of the jury know that at the time-at this particular time-in this particular community, we have been having a tremendous amount of killings; we have had an unusual number of shootings. It is up to you members of the jury . . ...").

o1 In somewhat less categorical language, Ohio courts appear also to have stringent rules against arguing deterrence. See, e.g., State v. Agner, 30 Ohio App. 2d 96, 104, 283 N.E.2d 443, 449 (1972) (arguments such as "we have to do something about it" and "we have a responsibility to stamp out this [drug] traffic" call for conviction as a duty to society and require reversal). See also State v. Davis, 60 Ohio App. 2d 355, 397 N.E.2d 1215 (1978).

${ }^{62}$ Hutchins v. Commonwealth, 255 S.E.2d 459, 461 (Va. 1979).

ss Id.

at Commonwealth v. Cherry, 474 Pa. 295, 305, 378 A.2d 800, 805 (1977).

os State v. Davis, 60 Ohio App. 2d 355, 362, 397 N.E.2d 1215, 1220 (1978). 


\section{The Functions and Effects of Deterrence Rhetoric}

States that continue to permit deterrence appeals rely on precedent developed generations ago. Although some judges in these states have questioned the continued validity of this precedert in light of modern views on criminal law, ${ }^{66}$ opinions sanctioning deterrence rhetoric generally refuse to articulate a rationale beyond the bald statement that such appeals have always been accepted..$^{67}$

This part considers the underlying justifications for deterrence appeals in greater depth. It analyzes the functions and effects of this oratorical form from four perspectives: the propriety of social policy arguments in the courtroom; the types of defendants against whom deterrence oratory has traditionally been invoked; the use of evidentiary principles to sanction such appeals; and the effect of courtroom argument on jurors' deliberations. In each case the justifications for deterrence appeals are tenuous at best, and the conclusion is that such rhetoric should be forbidden in criminal trials.

\section{A. Social Policy at Trial}

The fearless administration doctrine rests on the premise that prosecutors must be free to combat jury nullification-the tendency of jurors to acquit defendants contrary to the evidence and the judge's instructions on the law, for reasons of social policy or personal sympathy. Proponents of deterrence oratory argue that the effect of such rhetoric is not to encourage jurors to resolve doubts against defendants, but merely to discourage improper nul-

os See, e.g., Whittington v. State, 580 S.W.2d 845 (Tex. Crim. App. 1979), an opinion sanctioning the appeal for a guilty verdict "that your friends and neighbors can be proud of." In his candid concurrence Judge Clinton noted:

Were we hearing it for the first time, I would not hesitate to sound the critic's gong to the lyrical call of the prosecutor for a prideful verdict. It is, however, but a variation on a theme that has received generally favorable reviews .... .

Though dissonant to my own musical sense, the refrain is such a classic it will continue to receive critical acclaim until its hypocritical notes are more clearly heard. Meanwhile, in tune with stare decisis I concur in affirming the judgment of conviction. Id. at 847-48 (footnote omitted).

${ }^{67}$ Although it is difficult to measure the influence of precedent empirically, it is "one of the dominant facts in explaining why many local practices seem so ingrained." D. McIntyre, Criminal Justice in the Unitro States 50 (rev. ed. 1974); cf. State v. Burns, 119 Iowa $663,671,94$ N.W. 238,241 (1903) (rhetorical embellishments "have adorned the climax and peroration of legal oratory from a time 'whence the memory of man runneth not to the contrary,' and for us at this late day to brand their use as misconduct would expose us to great censure for interference with ancient landmarks"). 
lification sentiments when jurors believe defendants to be guilty. ${ }^{68}$ Such rhetoric, it has been argued, enables prosecutors to articulate a useful "touchstone of social conscience" to assist jurors in measuring the "social policy" implications of their verdict. ${ }^{69}$ This argument is flawed for several reasons. First, it ignores the evolution of the jury's function since the nineteenth century, when deterrence rhetoric first became an issue for judicial comment. Second, from occasional instances of nullification it draws an unwarranted assumption that juries generally ignore the social rules embodied in the criminal law. Finally, it presupposes that social policy issues are relevant to an evaluation of an individual's guilt or innocence.

Judges first advanced the fearless administration doctrine as a means to counteract their inability to limit the power of juries to the determination of facts. Well into the nineteenth century, juries in many states still were permitted both to decide the facts of the case and to adopt, modify, or reject the law itself at will. Judges' instructions in these states were viewed as merely advisory. ${ }^{70}$ In this unpredictable environment, judges recognized the "undoubted right" of prosecutors to make "fearless administration" appeals, 72

${ }^{8}$ See generally Scheflin, Jury Nullification: The Right to Say No, 45 S. CAs. L. Rev. 168 (1972). Jury analysts have suggested that the jury by its very nature acts like a legislature in giving content to "reasonableness" standards embodied in the criminal law. See P. Devlin, Trial by Jury 164 (3d ed. 1966); H. Kalven \& H. Zeisei, The American Jury 18290, 221-41 (1966).

In several states, the jury sits in a single proceeding to determine both the question of defendants' guilt or innocence and, if the verdict is guilty, the sentence. In the states with such "unitary" proceedings that also permit deterrence appeals, courts occasionally make a corollary assertion that such rhetoric affects only the jurors' second function. E.g., Hamilton v. Commonwealth, 401 S.W.2d 80, 87-88 (Ky. 1966), cert. denied, 385 U.S. 1014 (1967); State v. Blumer, 546 S.W.2d 790, 792 (Mo. Ct. App. 1977). As a matter of common sense, it is difficult to believe that jurors will be affected by deterrence appeals only with regard to the sentencing function, and ignore the same appeals when making the determination of guilt or innocence.

Crump, supra note 1 , at 527-28.

70 The question of the jury's duty to follow the judge's instructions of law engendered fierce ideological debates. See R. Eulis, The Jeprersonin Crisis: Courts and Polrtics in THE Young Republic 190, 197-98, 201-03 (1971). For a history of jury nullification and the evolving role of the jury in the nineteenth century, see Howe, Juries as Judges of Criminal Law, 52 HaRv. L. REv. 582 (1939); Note, The Changing Role of the Jury in the Nineteenth Century, 74 YALE L.J. 170 (1964).

In Illinois, where the fearless administration doctrine is particularly deeply embedded, the question of the jury's duty to follow the judge's instruction of law was not conclusively resolved until 1931, People v. Bruner, $343 \mathrm{Ill}$. 146, 175 N.E. 400 (1931), possibly explaining the state's traditionally stalwart defense of deterrence rhetoric.

71 Siebert v. People, 143 Hll. 571, 590, 32 N.E. 431, 436 (1892).

72 The expression "fearless administration" was first used by the Illinois courts in Sanders v. People, 124 III. 218, 225, 16 N.E. 81,83 (1888). 
defining the term as a "call upon the jury to sustain the laws." Deterrence appeals thus were originally sanctioned as a means to achieve a uniform administration of the laws and to limit "jury lawlessness."

Jury nullification has substantially eroded since judges' instructions of law were made binding in state and federal courts. ${ }^{74}$ Nullification in the face of binding instructions, however, has continued to play an infrequent but notable role in two contexts. First, juries historically have used their prerogative of nullification on rare occasions when asked to convict individuals for violating unpopular laws. Such "lawlessness" occurred in prosecutions under the fugitive slave laws and during Prohibition, for example; the controversy arose again in the Vietnam war era. ${ }^{75}$ Second, studies of the jury suggest that on occasion jurors exercise leniency when the case is one in which they can empathize with the defendant. ${ }^{76}$ Such cases include violations of gambling, game, and liquor laws; apparently the belief is that toleration of violations of such laws is widespread. ${ }^{77}$

Permitting admonitions for a fearless administration of such sumptuary legislation could conceivably be defended by arguing that jurors disinclined to enforce these laws should be reminded of their purpose and importance. ${ }^{78}$ Relying on these peripheral cases

7s Siebert v. People, 143 Ill. 571, 590, 32 N.E. 431, 436 (1892). See also People v. Wood, 318 III. 388, 149 N.E. 273 (1925).

74 The distinction between jury lawlessness in the nineteenth century and its modern, more restricted version is that traditionally the jurors were explicitly instructed to judge the laws for themselves, whereas today jurors can ignore the law through their unreviewable power to acquit the defendant despite conclusive evidence of guilt. The modern function is said to be a prerogative in fact as opposed to one in law. On this question of the balance between freedom and obligation of the criminal jury, see Kadish \& Kadish, On Justified Rule Departures by Officials, 59 Calip. L. Rev. 905 (1971); Scheflin, supra note 68.

78 See H. KALVEN \& H. ZEISEL, supra note 68, at 291 n.10; Scheflin, supra note 68, at 176-77.

76 H. KALVEN \& H. Zeised, supra note 68 , at 193-218, 301-38.

77 Id. at 286-97. See also W. CoRnish, The JuRY 119-20 (1968); Andenaes, The General Preventive Effects of Punishment, 114 U. PA. L. Rev. 949, 961 (1966) (discussing "morally neutral" fields of law, such as parking regulations, currency regulations, and price regulations).

7* In addition, it might be argued that because jurors are demonstrably inclined to treat drunk drivers sympathetically, see H. KALVEN \& H. ZEISEL, supra note 68, at 293-96, a prosecutor should be allowed to make an appeal for "fearless administration" because of the detrimental consequences of leniency. Many states permit such rhetoric. E.g., State v. Blumer, 546 S.W.2d 790, 792 (Mo. Ct. App. 1977) (jury asked to send a message advising the public that "drunk drivers are punished in Boone County"); Payne v. State, 164 Tex. Crim. $306,310,298$ S.W.2d 151, 155 (1957) (infliction of penalty would "go a long way" toward stopping "this kind of a thing on the highway"). The appeal is condemned in many other 
for a broad rule allowing deterrence rhetoric is problematical for two reasons, however. First, it suggests that some vague, undefined category of defendants-those for whom juries are likely to feel sympathy-should be subject to different standards of trial procedure. Second, it ignores the context in which the rule operates in the overwhelming majority of cases. The most frequent effect of the fearless administration doctrine is to sanction inflammatory and prejudicial deterrence appeals in cases in which jurors' sympathies have been shown to rest with the prosecution-offenses against property, narcotics sales, rape, and murder. ${ }^{79}$ Given the current tenor of public fear and outrage over the prevalence of crime in our society, ${ }^{80}$ it is inaccurate to maintain that jurors need to be incited into convicting for such offenses when they believe defendants to be guilty. ${ }^{81}$ It is far more likely that deterrence rhetoric, by injecting visceral appeals for the solution of social problems into emotion-laden trials, has the effect of undermining the fair, deliberate evaluation of an individual's guilt or innocence. Deterrence speeches become a means whereby the prosecutor, invoking threats to the safety of jurors' families and conjuring up the spectre of other criminals "out there . . . considering the odds," can undermine the presumption of innocence and implicitly ask jurors to adjust their thresholds of reasonable doubt for conviction. ${ }^{83}$

states. E.g., People v. Lewis, 52 Cal. App. 2d 824, 313 P.2d 972 (1957) (rhetoric, however, was harmless error).

Incredibly, at least two states-Georgia and Oklahoma-appear to condemn deterrence appeals against drunken-driving defendants as prejudicial but sanction similar appeals against felony defendants as proper appeals for fearless administration. Compare Collins v. State, 86 Ga. App. 157, 159-60, 71 S.E.2d 99, 101 (1952) and Seely v. State, 471 P.2d 931, 933 (Okla. Crim. App. 1970) with Brand v. Wofford, $230 \mathrm{Ga} .750,754,199$ S.E.2d 231, 234 (1973) (if acquitted, defendant will sell drugs to jurors' children) and Jones v. State, 555 P.2d 1061 (Okla. Crim. App. 1976) ("what are we gonna do about" murder).

7 H. KALVEN \& H. Zeisel, supra note 68 , at 395-410.

${ }^{80}$ One indication of the current mood is the simultaneous appearance this year of cover stories devoted to crime in the two most widely read American news magazines. See The Plague of Violent Crime, Newswzen, Mar. 23, 1981, at 46; The Curse of Violent Crime, ThMe, Mar. 23, 1981, at 16.

B1 Furthermore, a basically undemocratic notion seems to underlie any suggestion that incitement is the proper means for ensuring that juries render verdicts that are desirable from the standpoint of social policy.

${ }^{82}$ Cook v. State, 369 So. $2 d$ 1251, 1254 (Ala. 1979).

ss Many of the state courts that forbid deterrence appeals allude to the tendency of such arguments to undermine the reasonable doubt standard. See text and notes at notes 58-65 supra. The use of deterrence appeals would appear to violate the function of "reasonable doubt" as doubt "based on reason which arises from the evidence or lack of evidence," Johnson v. Louisiana, 406 U.S. 356, 360 (1972). 
Furthermore, those states that permit prosecutors to make social policy appeals condemn similar policy arguments by defendants in arguing for acquittal. Recognizing the jurors' de facto powers of leniency, courts do not allow nullification instructions; ${ }^{84}$ they forbid defense counsel to argue social policy in their summations, ${ }^{85}$ and, when defense counsel do make policy-oriented remarks, they recognize prosecutors' right to rebuttal. ${ }^{88}$ These prophylactic restrictions are premised on the belief that policy appeals by defendants, irrelevant to the question of guilt or innocence, invite "the ultimate logic of anarchy." ${ }^{\text {" }}$ In light of these restrictions on the defensive use of policy arguments, one can just as easily maintain that it is the unchecked use of deterrence rhetoric by the prosecutor that threatens the "ultimate logic" of tyranny.

In contrast to the jurisdictions where deterrence appeals are approved or at least tolerated, a small number of state courts have recognized the inherently prejudicial effect of deterrence oratory and explicitly rejected the logic of the fearless administration doctrine. ${ }^{88}$ Moreover, the American Bar Association's Standards Relating to the Prosecution Function and the Defense Function, ${ }^{89}$ the most ambitious attempt yet to define the proper scope of courtroom argument, states unequivocally:

s E.g., United States v. Dougherty, 473 F.2d 1113, 1133 (D.C. Cir. 1972) (defendants on trial for destruction of Dow Chemical property to protest manufacture of napalm were not entitled to nullification instruction); United States v. Moylan, 417 F.2d 1002, 1009 (4th Cir. 1969) (same with regard to clergy members claiming moral justification for destruction of draft files).

${ }^{8 s}$ E.g., Scott v. State, 51 Ala. App. 192, 197, 283 So. 2d 642, 647 (1973) (defense argument that "root causes of crime" are in society was not permitted because irrelevant to the question of guilt or innocence); State v. Reynolds, 41 N.J. 163, 195 A.2d 449 (1963); Rezeno v. State, 484 S.W.2d 374 (Tex. Crim. App. 1972). See generally Martin, Closing Argument to the Jury for the Defense in Criminal Cases, 58 J. CRIM. L.C. \& P.S. 2 (1967).

26 See text and notes at notes 184-187 infra.

87 United States v. Dougherty, 473 F.2d 1113, 1133 (D.C. Cir. 1972).

ss See text and notes at notes 58-59 supra. Consider the reasoning of the Michigan judiciary:

This Court is aware of the seriousness of the drug problem and realizes it touches the lives of many average citizens, generating much fear and dismay. We recognize, too, that jurors share the average citizen's desire to eliminate the narcotics traffic. In such an emotion-laden situation, sensibilities are easily inflamed. Because emotional reaction to social problems should play no role in the evaluation of an individual's guilt or innocence, prosecutors must exercise special care to avoid arousing jurors' emotions concerning such issues.

People v. Williams, 65 Mich. App. 753, 756, 238 N.W.2d 186, 187-88 (1975).

s9 ABA STANDARDs, supra note 7. 
(c) The prosecutor should not use arguments calculated to influence the passions or prejudices of the jury.

(d) The prosecutor should refrain from argument which would divert the jury from its duty to decide the case on the evidence, by injecting issues broader than the guilt or innocence of the accused under the controlling law, or by making predictions of the consequences of the jury's verdict.90

The ABA Standards have experienced an odd reception, however.91 Academic commentary often has approved the Standards while continuing to accept the fearless administration doctrine, ${ }^{92}$ thus failing to recognize or explore the mutually exclusive nature of these disparate doctrines. Many courts go to remarkable lengths to acknowledge the ABA Standards while utilizing traditional fearless administration doctrines ${ }^{93}$-an inconsistent reasoning process that lets prosecutorial policy appeals in through the back door.

\section{B. The Targets of Deterrence Rhetoric}

The reverence for the fearless administration doctrine also is misplaced because it ignores the types of defendants against whom deterrence oratory historically has been invoked. Many states at one time used the doctrine to sanction inflammatory, racially oriented deterrence arguments before white juries. They characterized appeals to jurors for convictions that would "throw a chill down the spine of every negro"94 and protect white women from the "brute lust" of of black men as "mere expression[s] of opinion

${ }^{20}$ Id. $\S 5.8(\mathrm{c})-(\mathrm{d})$.

o2 Only a few states have formally adopted the Standards. See, e.g., People v. Biondo, 76 Mich. App. 155, 256 N.W.2d 60 (1977); Commonwealth v. Cherry, 474 Pa. 295, 378 A.2d 800 (1977).

92 Compare J. StEIN, supra note $2, \S 14$ (responsibilities of prosecutors under ABA STANDARDS, supra note 7) with id. $\S 79$ (appeal to responsibility of jury proper); id. $\S 82$ (reference to increase or prevalence of crime proper); and id. $\S 83$ (appeal for fearless administration of the law proper).

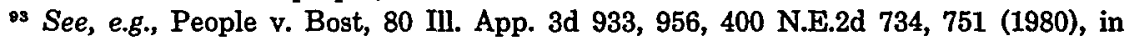
which the court held that the prosecutors' exhortation not to let the defendant "go loose on the streets" was not addressed to "making predictions of the consequences of the jury's verdict," but rather to "urging a fearless administration of the criminal law."

of King v. State, 141 Tex. Crim. 257, 258-59, 148 S.W.2d 199, 200 (1941) (conviction will "throw a chill down the spine of every negro in Gregg County and thereby stop some of these negro killings"; held permissible as "mild effort at oratory").

os Norman v. Commonwealth, 104 S.W. 1024, 1025 (Ky. Ct. App. 1907) (if black defendant not convicted, then "every negro in this commonwealth can go out and load himself with mean whiskey, and go subject any white woman, any white child, to the gratification of his brutal passion and brute lust"). 
as to the consequences of a failure to enforce the law"98 - the identical language currently used to define the nature of deterrence appeals and their effect on juries. ${ }^{97}$ Similar styles of argument were routinely permitted in many parts of the nation against other minority defendants. ${ }^{98}$ At first on the state level, ${ }^{98}$ and later as a matter of federal constitutional law applicable to the states under the fourteenth amendment, this type of argument came to be condemned; deterrence appeals explicitly invoking a defendant's race, creed, or ethnicity are now viewed as grounds for automatic reversal as a denial of due process. ${ }^{100}$

In light of this constitutional concern, it is inadequate to require prosecutors to avoid explicit expressions of prejudice against minorities while permitting them to use such prejudice, when cloaked in more subtle language, to the same inflammatory ends. ${ }^{101}$

- Cauley v. State, 156 Ark. 577, 579, 247 S.W. 772, 772 (1932) (argument that black defendant must be convicted to protect white women). See also Davis v. State, 209 Ala. 409, 410, 96 So. 187, 188 (1923) (although remark that "savage" instincts in blacks come from ancestral heritage in "the jungles of Africa" placed "too great stress" on defendant's ancestry, remark excused for lack of exception and caution from the bench); Jackson v. State, 136 Ala. 22, 25, 30, 34 So. 188, 189, 191 (1903) (legitimate to argue that if black defendant acquitted, "then, the first thing you know, [black mobs] will be taking a white man out and hanging him").

${ }_{97}$ E.g., Hill v. State, 253 Ark. 512, 530-31, 487 S.W.2d 624, 636 (1972).

is E.g., Rosenthal v. United States, 45 F.2d 1000, 1003 (8th Cir. 1930) (because the "business acumen of the Jewish race" was a recognized matter of common knowledge, statement that "I never knew of a Jew before that would surrender a piece of warehouse . . . for nothing" was permissible); People v. Reyes, 133 Cal. App. 574, 577, 24 P.2d 531, 532 (1933) (the "average Mexican" faces death "unflinchingly" and can take other lives calmly).

" Beginning early in this century, appellate courts in southern states began to exercise increasingly strict supervision over racial oratory in courtrooms. See Annot., 45 A.L.R.2d 303 (1956).

${ }^{100}$ See Miller v. North Carolina, 583 F.2d 701, 708 (4th Cir. 1978) (conviction required automatic reversal where prosecutor argued in rape case that there was no way a white woman would ever consent to having sexual relations with a black man); Kelly v. Stone, 514 F.2d 18, 19 (9th Cir. 1975) ( reversal required in rape case for argument that "maybe the next time it won't be a little black girl from the other side of the tracks; maybe it will be somebody you know"); United States ex rel. Haynes v. McKendrick, 350 F. Supp. 990, 9981006 (S.D.N.Y. 1972) (petitioner denied due process where prosecutor referred in closing argument to mannerisms, appearance, weaknesses, early sexual maturity, verbal inarticulateness, and hairstyles of blacks as a group), aff'd, 481 F.2d 152 (2d Cir. 1973).

${ }^{201}$ Many courts will not condemn racially oriented deterrence appeals unless they explicitly discuss race. E.g., United States ex rel. Kirk v. Petrelli, 331 F. Supp. 792, 795 (N.D. III.) (permissible to state that jurors should show people on "the south side of Chicago" that crime not tolerated), aff'd, 492 F.2d 1245 (7th Cir. 1971); State v. Rodriguez, 484 S.W.2d 203, 207 (Mo. 1972) (permissible to say that acquittal will "open up the floodgates" for a "summer of activity" of street violence). But see United States v. Haynes, 466 F.2d 1260 (5th Cir. 1972) (use of phrase "Burn, baby, burn" in closing argument highly prejudicial); Brown v. United States, 370 F.2d 242, 246 \& n.11 (D.C. Cir. 1966) (argument that if black 
No court has ever attempted to explain how minority defendants are any less prejudiced by appeals to "put the animals in the cages"102 than they are by outright racial slurs; both arguments have the same potential for undermining dispassionate analysis and inviting prejudice as an element in the calculus for conviction. Given the realities of the composition of the criminal docket and the suspicions prevalent in American communities, urban and rural, against particular classes of individuals-distinguished by race, lifestyle, ${ }^{103}$ or political belief ${ }^{104}$ - the use of deterrence rhetoric to strike deep-seated and often unconscious chords of prejudice against an accused "and everybody like him out there"10s is inconsistent with recent efforts to eradicate prejudice in the courtroom. The serious constitutional difficulties involved in such "us against them"108 oratory are not satisfactorily resolved by a mechanical application of the fearless administration doctrine.

An additional problem with deterrence rhetoric stems from the types of behavior against which it may be involked. For instance, deterrence appeals against defendants on trial for political crimes-subversion, espionage, draft evasion-traditionally have been condemned in the strongest terms. In Viereck $v$. United States, ${ }^{107}$ which involved the conviction of a German agent during World War II, the prosecutor in his summation had told jurors that they "have a duty to perform here"108 and that " $[t]$ he American people are relying upon you ladies and gentlemen for their protection against this sort of a crime, just as much as they are relying upon the protection of the men who man the guns in $\mathrm{Ba}$ -

defendant not convicted, "you might as well have martial law. You make the choice. You live with it," held, "in the context of current events," to be "an especially flagrant and reprehensible appeal to passion and prejudice."); Joyner v. State, $436 \mathrm{~S}$.W.2d 141, 144 (Tex. Crim. App. 1969) (deterrence argument that the country was on the "verge of anarchy," made shortly after the 1967 Detroit race riots, was reversible error).

${ }_{102}$ State v. Gray, 351 So. 2d 448, 460 (La. 1977). See also State v. Vernon, 251 La. 1099, 1114,208 So. $2 d 690,695$ (1968) (characterization of black defendant as an "animal" and question, "Who's safe in this city with men like him on the street?" permissible because evidence against defendant supported the invective).

${ }^{103}$ E.g., Smith v. State, 258 Ind. 594, 601, 283 N.E.2d 365, 369 (1972) (denunciation of "hippie[s] out of Chicago" before an Indiana jury); Greer v. Commonwealth, 455 S.W.2d 555, 557-58 (Ky. 1970).

204 See text and notes at notes 107-115 infra.

105 People v. Jackson, 19 Il. App. 3d 689, 695, 312 N.E.2d 405, 409 (1974).

108 This is a pervasive theme of deterrence oratory. See, e.g., cases cited notes 19, 29, 34, 37, 44 supra. See also J. OsBorn, The Mind of THE JuRor 92 (1937) (prejudice is the "thirteenth juror").

${ }^{207} 318$ U.S. 236 (1943).

${ }^{108} \mathrm{Id}$. at 247 n.3. 
taan Peninsula, and everywhere else." ${ }^{109}$ In dictum, ${ }^{110}$ Chief Justice Stone characterized this language as "offensive to the dignity and good order with which all proceedings in court should be conducted,"111 as well as "highly prejudicial"112 because it was spoken in a time of heightened emotions. Other courts have recognized that "when patriotism is at a high pitch," jus jurors are likely to lose their "mental poise,"114 so that appeals to "return a verdict in favor of America"11s violate the constitutional guarantee of a fair and impartial trial.

An arbitrary pattern of argument based on the type of alleged criminal activity results. ${ }^{116}$ No court has ever explained how ap-

${ }^{109} I d$.

110 The conviction was reversed because the trial judge's instructions on foreign agent laws were too broad; the defendant's activities "on behalf of" the Nazis consisted primarily of publishing and distributing fascist literature. Id. at 242-45.

11 Id. at 248.

112 Id.

113 Hall v. United States, 256 F. 748, 752 (4th Cir. 1919) (violation of Espionage Act). 114 Id.

11 Bary v. United States, 248 F.2d 210, 213 (10th Cir. 1957) (in prosecution under the Smith Act for conspiracy to organize Communist Party, prosecutor also dwelt upon the Cold War and the possibility of actual war between the United States and Russia). For other examples of inflammatory patriotic appeals, see Taglianetti v. United States, 398 F.2d 558 (1st Cir. 1968) (remarks in tax evasion case that defendant deprives the country of "the dollars and cents we need in the till to fight Communism, to fight the war in Viet Nam"), aff'd, 394 U.S. 316 (1969); Greenberg v. United States, 280 F.2d 474 (1st Cir. 1960); Elmer v. United States, 260 F. 646 (8th Cir. 1919); August v. United States, 257 F. 388, 393 (8th Cir. 1918) (in prosecution for bribery to evade the draft, prosecutor told jury that its verdict would "waft its way to the agents of hell opposed to us across the mighty waters, and there, gentlemen, the verdict of this jury will be read and heard by the war lords of Germany as a beat from the pulse of the American people").

116 Although case law is sketchy, it also appears to be the settled practice to condemn deterrence oratory for white-collar offenses such as tax evasion and antitrust violations. See United States v. Cotter, 425 F.2d 450 (1st Cir. 1970) (argument at time of first moon landing in tax evasion case that if people do not pay their taxes there will be no more moon landings); Taglianetti v. United States, 398 F.2d 558, 566 (1st Cir. 1968) (tax evasion harms Vietnam war effort); United States v. Sprengel, 103 F.2d 876, 884 (3d Cir. 1939) (mail fraud: "We have got to convict these people. They will go wild with this kind of thing. The only way it can be done is by conviction."); J. STEIN, supra note $2, \S 81$. See also United States v. Socony-Vacuum Oil Co., 310 U.S. 150 (1940), an antitrust case in which the prosecutor urged jurors to control "malefactors of great wealth," these "eager, grasping men" who "take the law into their own hands . . . without any consideration for the underling or the poor man .... We are going to stop it . . or we are going down into ruin as did the Roman Empire." Writing for the Court, Justice Douglas characterized this language as a "highly improper" appeal to class prejudice; the trial judge's curative instruction, however, was deemed sufficient to cure the error. Id. at 238-43.

Some courts and commentators have offered disconcerting categorizations of different types of criminal activity to justify disparate rhetorical standards based on the nature of the offense. Compare J. STEIN, supra note 2, § 81 (appeals to jurors' interests as taxpayers im- 
peals to stand by one's family and community are any different in their potential for prejudicial impact from appeals to stand by one's country. It is anomalous to suggest that jurors' emotions and prejudices are impermissibly ignited by appeals to national security interests, but that analogous appeals to civic and family security against social violence are acceptable.

\section{The Evidentiary Underpinnings of Deterrence Oratory}

Judges historically have granted "wide latitude" to prosecutors in arguing inferences, deductions, and analogies from evidence introduced at trial. ${ }^{117}$ This presumption that each side must be free to argue its theories of the case, however "forced, unnatural, and untenable," is based on the premise that partisan advocacy best promotes the objectives of the jury fact-finding process. ${ }^{118}$

State courts defending deterrence appeals under the "wide latitude" theory frequently neglect to balance the need for vigorous summation against the modern, limited functions of closing argument. Although unrestrained argument between the defendant and counsel for the Crown was characteristic of English criminal trials in the sixteenth and seventeenth centuries, procedural reforms commencing early in the eighteenth century have shifted the function of argument to evidentiary summation at the close of trial.119 The purposes of closing argument are to provide the jury with analysis of contested and uncontested evidence, "sharpen and clarify issues for resolution," explain difficult concepts of law, and suggest to the jury whether the burden of proof has been met. ${ }^{120}$

Courts allowing deterrence appeals in the face of these narrow functional purposes generally recognize that closing argument is governed by the rules of evidence. ${ }^{121}$ Their categorization of deter-

proper) with $\S 83$ (appeals for law enforcement proper); compare 75 AM. Jur. 2D Trial $\S \S 287,288$ (1974) (appeals to prejudice against corporations and class prejudice improper) with id. § 225 (remarks illustrating "evil consequences" of failure to perform jury duties proper). See also Crump, supra note 1, at 526 (deterrence appeals focusing on conditions within the jurors' community are proper, as opposed to those "relating to external criminal acts or conditions in the country or in other communities"). 1940).

117 J. STEIN, supra note 2, § 15. See generally 6 J. WigmoRe, EvidENCE § 1807(3) (3d ed.

1186 J. WIGMORE, supra note 117, § 1807(3); see Herring v. New York, 422 U.S. 853, 862 (1975) (extending through the fourteenth amendment the right to closing summation in all state nonjury criminal trials).

12 Herring v. New York, 422 U.S. 853, 860-61 (1975).

120 Id.; J. STEIN, supra note 2, § 2; Crump, supra note 1, at 506.

121 See, e.g., People v. Durso, 40 ml. 2d 242, 253, 239 N.E.2d 842, 848 (1968), cert. de- 
rence appeals as reasonable inferences from the evidence and as matters of "common knowledge" subject to judicial notice is subject to attack, however. Jurors sit solely to adjudicate the issue of a defendant's guilt or innocence based on what he did, when, where, how, and with what motive or intent. ${ }^{122}$ By any accepted standard of relevance, ${ }^{123}$ arguments that conviction of the defendant will deter others from similar offenses ${ }^{124}$ are neither probative of a defendant's guilt nor themselves matters properly provable in the case. Even if such arguments were relevant, they would be impermissibly prejudicial because their probative value is outweighed by the emotional responses they invite. ${ }^{125}$

Wigmore defined the logical process of drawing inferences from the evidence as a matter of persuading the trier of fact that fact $A$ follows from fact $B .{ }^{128}$ In this "domain of logic"12z the prosecutor is free from restraint. The premise for permitting this wide latitude is that all asserted inferences, however implausible, are by definition relevant because the evidence supporting the logical assertions would not have been admitted in the first place if it had been devoid of probative value. ${ }^{128}$ Many state appellate courts misconstrue this principle; it is difficult to perceive how appeals urging jurors to "picture yourself witnessing the rape of one of your loved ones,"129 or asserting that acquittal will "justify" criminal behavior, ${ }^{130}$ that if "these animals on the street" are not "caged where they belong," they will "dictate in our county,"1s1 and that unless convicted "these human vultures [will] crawl on the bellies of our

nied, 393 U.S. 1111 (1969); Jones v. State, 555 P.2d 1061, 1066 (Okla. Crim. App. 1976). Texas, however, has explicitly exempted its "plea for law enforcement" doctrine from the rules of evidence. E.g., Alejandro v. State, 493 S.W.2d 230, 231-32 (Tex. Crim. App. 1973).

${ }^{122}$ See Davis, Judicial Notice, 55 Colum. L. Rev. 945, 952 (1955).

${ }^{123}$ See generally FED. R: EvID. 401-402 \& Advisory Comm. Notes; 1 J. Wrgmore, supra note $117, \S \S 27-29$.

124 Examples of "deterrence evidence" would include FBI crime statistics for the jurors' community, opinion polls demonstrating the degree of public concern for crime, expert testimony on the sociologicial effects of law enforcement as a deterrent to would-be criminals, and so forth.

225 See generally Fed. R. Evid. 403 \& Advisory Comm. Notes; 1 J. Wigmore, supra note 117, \& 29(a); Dolan, Rule 403: The Prejudice Rule in Evidence, 49 S. CaL. L. REv. 220, 22044 (1976).

${ }^{128} 6 \mathrm{~J}$. WIGMORE, supra note 117, § 1807(3); see id. $\S 1$ (argument and evidence distinguished).

${ }^{127}$ Id. $\S 1807(3)$.

128 Id.; see 1 id. $\S \S 9,28$.

120 Parks v. State, 400 S.W.2d 769, 771 (Tex. Crim. App. 1966).

130 State v. Rodriguez, 484 S.W.2d 203, 207 (Mo. 1972).

131 Costilla v. State, 609 P.2d 788, 790 (Okla. Crim. App. 1980). 
helpless and defenseless women"132 are the product of logical reasoning from the evidence.

Deterrence arguments are defended by some courts as matters that are "common knowledge" or subject to judicial notice. ${ }^{133}$ These doctrines can have no application to deterrence rhetoric. First, the proposition that "conviction deters" is not within the narrow realm of "elemental experience" encompassed by the doctrines. ${ }^{134}$ More fundamentally, even matters of common knowledge and judicial notice cannot provide a basis for argument where they are not admissible in the case. ${ }^{135}$ Argument may be based on inferences from record evidence or on matters commonly known, but such rhetoric must, like record evidence, be probative of the defendant's guilt or innocence. ${ }^{136}$

Thus shorn of evidentiary underpinnings, deterrence appeals would appear to violate the hearsay rule and the sixth amendment.

${ }^{132}$ Hill v. State, 144 Tex. Crim. App. 415, 423, 157 S.W.2d 369, 373 (1941), rev'd on other grounds, 316 U.S. 400 (1942).

${ }^{138}$ E.g., Embrey v. State, 283 Ala. 110, 214 So. 2d 567, 575-76 (1968) (argument that "[w]e all know the crime rate is rising and rising and rising. . . . You have got to determine whether or not these juries are going to stop these robberies from going on" proper because prevalence of crime is "a matter of common knowledge in that it has been discussed in the press, on radio and television for many, many months"); Robinson v. State, 47 Ala. App. 51, 54, 249 So. 2d 872, 875 (1971) (reference to recent fire bombings in Mobile in arson prosecution).

1s، The universe of facts embraced by the "common knowledge" doctrine has been defined as those facts so universal, notorious, or unquestioned as to make it unprofitable to require proof of their existence. Statements that fire-burns, that the period for human gestation is normally nine months, or that a particular well-known street lies in the business district of town are not objectionable because requiring formal proof of such facts would be a waste of judicial resources. Historical and literary analogies also are admitted under the "common knowledge" doctrine to illustrate difficult principles of law or processes of reasoning. See generally J. McCormick, Evidence \$§ 328-329 (2d ed. 1972); 6 J. Wigmork, supra note 117, § 1807; 9 id. \& 2570 (counsel may "ask the jury to refer to their general knowledge") (emphasis omitted)); Levin \& Levy, Persuading the Jury with Facts Not in Evidence: The Fiction-Science Spectrum, 105 U. PA. L. REv. 139 (1956); Morgan, Judicial Notice, 57 HaRv. L. REv. 269 (1944).

1ss See 6 J. Wigmore, supra note 117, § 1806 (courtroom argument "must be based solely upon those matters of fact which evidence has already been introduced or of which no evidence need ever by introduced because of their notoriety as judicially noticed facts").

${ }^{238}$ The division of the fact-finding process into the search for legislative facts on the one hand and adjudicative facts on the other also undermines the case for deterrence oratory. Adjudicative facts, which relate to the particular event that gave rise to the litigation-questions of "who did what, when, where, how, and with what motive or intent"-are within the jury's realm. J. McCoRMICK, supra note 134, $\$ 328$. Legislative facts include social, economic, and political data used in "informing a court's legislative judgment on questions of law and policy." Davis, An Approach to Problems of Evidence in the Administrative Process, 55 HaRv. L. Rkv. 364, 404 (1942). Deterrence appeals are strictly legislative concerns. 
Arguments not properly based on record evidence, judicial notice, or the common knowledge doctrine render the prosecutor himself an unsworn witness not subject to cross-examination, thus violating the fundamental principle of the hearsay rule. ${ }^{137}$ In addition, permitting the prosecutor to go beyond the record in his closing argument, with no right of reply, violates the defendant's sixth amendment right to confront and interrogate adverse witnesses. ${ }^{133}$

\section{The Sporting Theory of Courtroom Argument}

Although the fearless administration doctrine is subject to criticism on functional, historical, and evidentiary grounds, state courts occasionally offer an additional defense of deterrence oratory: such rhetoric fully comports with the "sporting theory of justice,"139 the view that a criminal trial " is a legal battle, a combat in a sense, and not a parlor social affair." "140 The tradition of "great advocates whose logic glowed and flowed with the heat of forensics"141 is deeply embedded in our popular culture, and the suggestion of rhetorical limitations strikes many as leading to "listless, vigorless summation of fact in Chesterfieldian politeness." 142

137 ABA STANDARDS, supra note 7, commentary to $\$ 5.8(\mathrm{a})$ (arguments not based on record evidence are "assertions of fact not proved [and] amount to unsworn testimony of the advocate not subject to cross-examination"); $6 \mathrm{~J}$. WIGMORE, supra note 117, \& 1806.

${ }^{128}$ See generally Parker v. Gladden, 385 U.S. 363 (1966); 5 J. WIGMORE, supra note $117, \S 1364$ ("The right of confrontation is the right to the opportunity of crassexamination").

Justice Douglas frequently advocated a more vigorous use of the confrontation clause to control prosecutors' rhetorical excesses in state and federal proceedings, arguing that the prosecutor's function "is not to tack as many skins of victims as possible to the wall," and that "[t]he prosecutor is not a witness; and he should not be permitted to add to the record either by subtle or gross improprieties." Donnelly v. DeChristoforo, 416 U.S. 637, 650-51 (1974) (Douglas, J., dissenting). This approach is treated analytically in Carlson, Argument to the Jury and the Constitutional Right of Confrontation, 9 CRIM. L. BuLl. 293 (1973).

130 The expression is from Roscoe Pound, who characterized this attitude as "only a survival of the days when a lawsuit was a fight between two clans" in his seminal essay The Causes of Popular Dissatisfaction With The Administration of Justice, 29 A.B.A. RkP. 395, 404-06 (1906).

110 Price v. State, 388 So. 2d 517, 520 (Ala. Crim. App. 1977) (quoting Arant v. State, 232 Ala. 275, 280, 167 So. 540, 544 (1936)).

141 Ballard v. United States, 152 F.2d 941, 943 (9th Cir. 1945), rev'd on other grounds, 329 U.S. 187 (1946).

${ }^{142}$ Id. See also United States v. Wexler, 79 F.2d 526, 530 (2d Cir. 1935) (L. Hand, J.) ("a jury inevitably catches this mood and . . . the truth is not likely to emerge, if the prosecution is confined to such detached exposition as would be appropriate in a lecture, while the defense is allowed those appeals in misericordiam which long custom has come to sanction"), cert. denied, 297 U.S. 703 (1936); Nelms \& Blum Co. v. Fink, 159 Miss. 372, 383, 131 So. 817,820 (1930) (prosecutor "may explore all the shores of thought and experience; he 
A corollary assertion-usually implicit, on occasion articulated-is that jurors take these appeals at their "true worth":143 as "mere argument"144 and not as evidence to be weighed in reaching their verdict. These courts assert that innocent defendants are not convicted by deterrence rhetoric, on the grounds that such a notion attributes to the jury a "stupidity and absence of common sense which is incredible."145 If the defendant is guilty, on the other hand, then the deterrence considerations are viewed as fully justified. ${ }^{146}$

Such defenses of deterrence rhetoric are questionable for several reasons. First, ex post justifications advanced by prosecutors and trial judges-that if a defendant is guilty, deterrence appeals may be invoked to reinforce this determination by the jury, whose fact-finding function is to determine guilt or innocence-run counter to the principle of a presumption of innocence until conviction in a fair and impartial trial governed by uniform procedure. $^{147}$

Furthermore, the "true worth" argument is empirically unfounded. While the impact of oratory on individual jurors is an inherently speculative matter, ${ }^{148}$ many jurists and commentators have rejected the "true worth" rationale. The prosecutor occupies a position of considerable prestige; ${ }^{149}$ the Supreme Court recog-

may, if he will, take the wings of the morning and fly not only to the uttermost parts of the sea but to the uttermost limits of space in search of illustrations, similes, and metaphors to adorn his argument").

143 Price v. State, 348 So. 2d 517, 520 (Ala. Crim. App. 1977).

144 United States v. Kravitz, 281 F.2d 581, 586 (3d Cir. 1960).

${ }^{145}$ Id. See also DiCarlo v. United States, 6 F.2d 364, 386 (2d Cir.) ("To sheer [the prosecutor] of all oratorical emphasis ... is to deny what has always been an accepted incident of jury trials, except in those jurisdictions where any serious execution of the criminal law has yielded to a ghostly phantom of the innocent man falsely convicted"), cert. denied, 268 U.S. 706 (1925); State v. Burns, 119 Iowa 663, 671, 94 N.W. 238, 241 (1903) ("[Rhetorical excesses] give zest and point to the declamation, relieve the tediousness of the juror's duties, and please the audience, but are not often effective in securing unjust verdicts.").

${ }^{148}$ See State v. Gray, 351 So. 2 d 448, 460 (La. 1977), where in sanctioning an appeal to "put the animals in the cages," the court asserted that "[c]ertain morally reprehensible conduct, such as that in issue in the present case, defies characterization as civilized behavior and may more faithfully be described as that of an animal."

${ }_{147}$ Cf. State v. Cyty, 50 Nev. 256, 256 P. 793, 794 (1927) ("if the state has a strong case, it is not necessary, and if it has a close case, such misconduct is gross injustice to the defendant").

${ }^{148}$ See, e.g., Kalven, Advocacy and the Jury System: The Impact of the Trial Lawyer, 44 F.R.D. 169 (1968).

149 See generally ABA StANDARds, supra note 7, at 18-21; The Prosecutor in America (J. Douglas ed. 1977). 
nized long ago that because of this respect for the office, "improper suggestions [and] insinuations . . . are apt to carry much weight against the accused."150 At the culmination of trial, closing argument carries a "significant persuasive force"; 151 it has been recognized since antiquity ${ }^{\mathbf{1 6 2}}$ that in cases "where the skill of counsel can make the difference, it is the closing argument more than any other single stage of the case that determines who wins or who loses."15s Although deterrence appeals sometimes are employed in situations where guilt cannot be doubted, they are often found in cases turning on sharp factual disputes for resolution by the jury-matters of conflicting evidence and witness credibility, ${ }^{154}$ provocation, ${ }^{158}$ and the insanity defense. ${ }^{158}$

The assertion that deterrence rhetoric does not affect jurors' deliberations ignores an important premise of our criminal trial procedure, namely, that jurors frequently do have biases and weaknesses. ${ }^{187}$ Rules governing voir dire examination and pretrial publicity $^{158}$ seek to minimize this potential for bias; rules of evidence seek to ensure a carefully controlled presentation of relevant, probative formal evidence. ${ }^{158}$ Other forms of rhetorical license have

130 Berger v. United States, 295 U.S. 78, 88 (1935).

182 ABA STANDARDS, supra note 7, commentary to $\$ 5.8$.

${ }^{163}$ See Aristotle's admonition to the prosecutor that "the accuser must create prejudice in the epilogue, that his hearers may have a livelier recollection of it." ARISTOTLE, RHETORIC 3.14 (J. Freese trans. 1926).

183 J. Kaplan \& J. Waltz, The Trial of Jack Ruby 310 (1965); accord, F. BaIley \& H. RothblatT, Fundamentals of Criminal Advocacy $\$ 444$ (1974).

15t E.g., Perry v. Mulligan, 399 F. Supp. 1285 (D.N.J. 1975), rev'd sub nom. United States ex rel. Perry v. Mulligan, 544 F.2d 674 (3d Cir. 1976), cert. denied, 430 U.S. 972; Reid v. State, 119 Ga. App. 368, 370, 166 S.E.2d 900, 902 (1969); People v. Van Zile, 48 Ill. App. 3d 972, 984, 363 N.E.2d 429, 438 (1977); Clark v. State, 264 Ind. 524, 536-37, 348 N.E.2d 27, 35-36 (1976) (harmless error); Greer v. Commonwealth, 455 S.W.2d 555, 557-58 (Ky. 1970).

1ss E.g., State v. Moore, 112 Ariz. 271, 274, 540 P.2d 1252, 1255 (1975); People v. Benedik, 56 Ill. 2d 306, 310-11, 307 N.E.2d 382, 385 (1974); State v. Rodriguez, 484 S.W.2d 203, 207 (Mo. 1972).

${ }^{156}$ E.g., State v. Karstetter, 110 Ariz. 539, 543-44, 521 P.2d 626, 630-31 (1974); Jacks v. State, 394 N.E.2d 166, 176 (Ind. 1979).

167 The use by prosecutors of standard rules of thumb, computerized data, and psychological evaluations in choosing certain "types" of jurors based on sex, age, family background, and occupation in order to assemble a jury with "favorable attitudes" toward the prosecution increases the probability that jurors will be swayed by rhetorical appeals. See $R$. Simon, The JuRY: Its Role in Amrrican Society $29-47$ (1980); Note, The Constitutional Need for Discovery of Pre-Voir Dire Juror Studies, 49 S. CAL. L. REv. 597 (1976); cf. F. BAILEY \& H. RothBLATT, supra note 153, \$\$ 318-342 (jury selection by defense counsel).

1sa See Nebraska Press Ass'n v. Stuart, 427 U.S. 539 (1976); Murphy v. Florida, 421 U.S. 794 (1975); Sheppard v. Maxwell, 384 U.S. 333 (1966).

185 See notes 123, 125 supra. 
been forbidden because their "true worth" is viewed as prejudicial. ${ }^{160}$ The casual attitude toward deterrence rhetoric in many state courts fails to appreciate the potential impact of such appeals and ignores the inconsistency of the "sporting theory" with modern trial procedure.

\section{The Enforcement of Rhetorical Standards}

Clear rhetorical standards are the necessary first step in eliminating deterrence appeals from the courtroom. The ABA Standards referred to earlier offer a useful model. ${ }^{161}$ It would be an empty gesture, however, to adopt such standards without taking stern measures to enforce them, for "[i]f we continue to do nothing practical to prevent such [mis]conduct, we should cease to disapprove it." "162 In addition to defining clear standards of acceptable rhetoric, an effective procedural framework must encourage defense counsel to object to appeals that violate the standards, place the burden of eliminating such rhetoric on prosecutors and trial judges, and preserve scarce appellate resources by controlling deterrence appeals at the trial level.

The procedures adopted in many states, however, foster exactly the opposite results. Standards remain undefined; the burden of eliminating this rhetoric is cast upon defense counsel; trial judges are given virtually free license to set whatever rhetorical standards they wish; and appellate courts are increasingly burdened with reviewing prosecutorial misconduct. Deterrence appeals receive implicit approval, thus perpetuating a confident cynicism among prosecutors that the tolerable range of misconduct is broad. Judge Frank, condemning this attitude of "helpless piety" toward rhetorical abuses, noted the effective judicial message to prosecutors:

${ }^{180}$ See text and notes at notes 2-6, 100-101, 107-115 supra.

281 See text and note at note 90 supra. Michigan and Pennsylvania have adopted the Standards as a model for courtroom argument. See notes 58-59, 91 supra.

Because it is impossible to anticipate and define all varieties of deterrence appeals in advance, one might argue that any effort to eradicate such rhetoric by means of a clear rule would be quixotic. This argument is unpersuasive. Problems of line drawing are encountered in all rules governing rhetoric. Determining when an argument violates the Griffin stricture, asserts personal knowledge of defendant's guilt, or appeals to prejudice, frequently is diffcult, but difficulties in fixing the exact scope of these rules should not call the legitimacy of the rules themselves into question.

${ }^{182}$ United States v. Antonelli Fireworks Co., 155 F.2d 631, 661 (2d Cir.) (Frank, J., dissenting), cert. denied, 329 U.S. 742 (1946). 
"Government attorneys, without fear of reversal, may say just about what they please in addressing juries, for our rules on the subject are pretend-rules. ... The deprecatory words we use in our opinions are purely ceremonial." Government counsel, employing such tactics, are the kind who, eager to win victories, will gladly pay the small price of a ritualistic verbal spanking. The practice of this court-recalling the bitter tear shed by the Walrus as he ate the oysters-breeds a deplorably cynical attitude towards the judiciary. ${ }^{163}$

Procedural responses vary significantly between the states manifesting a determination to discourage deterrence rhetoric and those employing an essentially laissez-faire approach. This part examines these contrasting frameworks to identify the procedural approaches that serve the needs of prudent judicial administration while preserving the rights of defendants.

\section{A. The Harmful Effects of Harmless Error}

The harmless error doctrine is premised on the belief that intolerable social costs would result if every trial error required reversal and retrial. ${ }^{184}$ This doctrine is used extensively in reviewing rhetorical excesses by prosecutors. ${ }^{165}$ Many jurisdictions refuse to reverse convictions even where the trial judge overrules defense objections to inflammatory deterrence appeals, reasoning that such rhetoric could not possibly have operated to convict an innocent defendant. ${ }^{168}$ In the context of rhetorical misconduct, the harmless error doctrine is abused in several respects.

163 Id.

19s The adverse effects of the harmless error doctrine are by no means unique to rhetorical standards. The doctrine is used to review a broad range of trial errors, and has been the subject of significant judicial and academic criticism. See R. Traynor, ThE RIDDLE op Harmless Error (1970); Field, Asssessing the Harmlessness of Federal Constitutional Error-A Process in Need of a Rationale, 125 U. PA. L. REv. 15 (1976); Note, Harmful Use of Harmless Error in Criminal Cases, 64 CoRnel. L. Rev. 538 (1979); Comment, Principles for Application of the Harmless Error Standard, 41 U. CHI. L. REV. 616 (1974).

$16 s$ See, e.g., Dunlop v. United States, 165 U.S. 486, 498 (1897):

There is no doubt that, in the heat of argument counsel do occasionally make remarks that are not justified by the testimony, and which are, or may be, prejudicial to the accused. . . . If every remark made by counsel outside of the testimony were ground for a reversal, comparatively few verdicts would stand, since in the ardor of advocacy, and in the excitement of trial, even the most experienced counsel are occasionally carried away by this temptation.

18s Jacks v. State, 394 N.E.2d 166, 176 (Ind. 1979) (harmless, thought not "commendable," to argue that if defendant acquitted by reason of insanity he would go free and walk "the same streets" as jurors); Clark v. State, 264 Ind. 524, 536-37, 348 N.E.2d 27, 35-36 
Harmless error is used in many states to avoid any attempt to enunciate standards for closing argument in the first place. Many state courts decline to rule on the propriety of deterrence appeals because the error, "if any," is viewed as harmless. ${ }^{167}$ This recurrent refusal to elaborate the permissible bounds of prosecutorial rhetoric leaves trial judges and counsel without any sense of the standards that should be followed.

A second misuse of harmless error occurs in setting the threshold for probable prejudice of rhetorical abuses. In many states the defendant must prove not only the existence of rhetorical error, but also that the error resulted in "sufficiently grave"168 juror hostility as to place him in "grave peril"168 of improper conviction. Because the effect of prosecutorial argument in a given case is an inherently speculative consideration, not subject to easy identification or quantification, ${ }^{170}$ it is virtually impossible to meet this burden of demonstrating prejudicial impact.

(1976) (harmless error for prosecutor to urge jurors to disregard testimony of two witnesses as a matter of civic duty); Hatcher v. State, 230 Miss. 257, 261-67, 92 So. 2d 552, 555-57 (1957) (harmless error to argue that "these good Lauderdale County people sitting out in this audience . . . . are wondering whether this sort of thing is going to be licensed"); Jones v. State, 610 P.2d 818, 820 (Okla. Crim. App. 1980) (questioning whether jurors had the "intestinal fortitude" to stop crime held to be harmless error).

It is also the usual practice of federal appellate courts to criticize deterrence rhetoric while using harmless error analysis to uphold convictions in federal jury trials. See, e.g., United States v. Hawkins, 595 F.2d 751, 754-55 (D.C. Cir. 1978) (prosecutor may not substitute emotion for evidence by equating, directly or by innuendo, a verdict of guilty with a blow against the drug problem; error, however, was harmless), cert. denied, 441 U.S. 910 (1979); United States ex rel. Clark v. Fike, 538 F.2d 750, 759-60 (7th Cir. 1976), cert. denied, 429 U.S. 1064 (1977).

${ }_{162}$ People v. Simbolo, 188 Colo. 49, 53, 532 P.2d 962, 964 (1975) (district attorney "may have gone too far" in arguing that community must be protected from rapists like the defendant); Maldonado v. State, 265 Ind. 492, 501, 355 N.E.2d 843, 849 (1976) (recognizing without resolving ambiguous lines of precedent); Warner v. State, 265 Ind. 262, 265-66, 354 N.E.2d 178, 181 (1976); Greer v. Commonwealth, 455 S.W.2d 555, 557-58 (Ky. 1970) (diatribe against "hippie[s]" was a reasonable presentation of case; if it was not, it was harmless error); Terrell v. State, 262 So. $2 d 179$ (Miss. 1972) (district attorney "probably should not have made" statement that outsiders will "get [the] message" that juries are not "tough" if defendant acquitted); Overstreet v. State, 470 S.W.2d 653, 654 (Tex. Crim. App. 1971).

${ }^{163}$ This is the test in North Carolina. State v. Hunter, 28 N.C. App. 465, 467-68, 221 S.E.2d 837 (1976) (if defendant acquitted, "then law and order in this country might as well go, too").

${ }^{189}$ This is the test required by Indiana. Maldonado v. State, 265 Ind. 492, 501, 355 N.E.2d 843 (1976) ("This may be the most important thing you'll ever do for your community. A chance to serve and do your duty ....").

170 See, e.g., Kalven, supra note 148, at 170. Professors Kalven and Zeisel noted that their empirical study of jury behavior "has . . . joined that distinctive group of books that can be quoted on both sides of the issue" of the prejudicial impact of prosecutors' disclosure to the jury of defendants' prior criminal records. H. KaLveN \& H. ZRISBL, supra note 68, at 
Harmless error analysis also invites judges to review the trial record to ascertain whether, absent the error, there was enough evidence to support the conviction; this amounts to a usurpation of the jury's traditional role as sole finder of fact, and can provide few principled guidelines for lower courts. ${ }^{171}$ Finally, abusive use of harmless error undercuts the supervisory responsibilities of state appellate courts to define and enforce proper courtroom procedures, thus removing incentives for trial judges and prosecutors to abide by the rules. The doctrine operates effectively to curtail a defendant's right to be judged solely on the basis of guilt or innocence.

By contrast, a number of state courts employ harmless error with scrupulous care to avoid these consequences. Rather than using the doctrine to avoid defining rhetorical limits, these states attempt to articulate "clearly defined" rules of argument for prosecutors to observe and trial judges to enforce. ${ }^{172}$ These guidelines are reinforced by strict standards for review. Rather than placing the burden on the defendant to prove that deterrence appeals placed him in "grave peril," some states, upon determining that the prosecutor has engaged in forbidden argument, require the state to prove no "reasonable possibility" for prejudicial impact. In other states, courts refuse to engage in harmless error analysis at all when the trial judge permits violations to go unchecked; they

vi (Phoenix ed. 1971).

171 Judge Joe R. Greenhill of the Texas Supreme Court has suggested that the harmless error doctrine should be translated to read, "The judge sure goofed up the trial, but we think the defendant is guilty anyway, so what the hell." Quoted in Alschuler, supra note 1, at 658-59. See also Field, supra note 164, at 35 ("Such a practice is difficult to reconcile with the accepted rule that a trial judge may not direct a verdict against a defendant in a criminal case, regardless of the strength of the evidence against him."); Note, supra note 164 , at 543 .

Apart from problems of usurping jury functions, the harmless error doctrine, though asserted to be a mechanism for the conservation of scarce judicial resources, has increased appellate workloads significantly. See id. at 544. See also United States v. Freeman, 514 F.2d 1314, 1321 (D.C. Cir. 1975) ("Despite . . . verbal slaps-on-the-wrist, prosecutorial misconduct continues to provide 'one of the most frequent contentions of defendants on appeal.' Our experience thus suggests that courts must begin to take prophylactic considerations together with probable prejudice to defendant in deciding whether to reverse." (footnote omitted) (quoting Alschuler, supra note 1, at 631)).

172 People v. Farrar, 36 Mich. App. 294, 299, 193 N.W.2d 363, 366 (1971); see cases cited notes 60-62 supra.

173 See, e.g., Commonwealth v. Reynolds, 254 Pa. Super. 454, 460, 386 A.2d 37, 41 (1978). This standard would still permit the state to avoid retrial if the effect of the error was demonstrably minimal; evidence might include the ambiguity of the appeal, failure to object, curative measures taken at trial, and provocation by defense counsel. 
argue that "[u]nless we enforce the rules we encourage their violation and add to the burden of appellate courts . . . . [Prosecutors and trial judges] have only themselves, not the appellate courts, to blame if a judgment of conviction is reversed and must be retried because of improper argument."174

\section{B. Courtroom Procedures}

The role of the trial judge should be of central concern in procedural reform. Where rhetorical abuse occurs, the trial judge can take appropriate curative action to guard defendants' rights and make appellate review unnecessary. Moreover, strong prophylactic rules focused on defining standards for judicial response to rhetorical excess can exert a great deterrent effect on courtroom misbehavior. State appellate courts, however, generally grant a wide range of discretion to the trial judge in setting courtroom standards, based on the finding that only trial judges are in the position to "evaluate the impact of argument complained of."175 Without clearly defined rules of argument, unsympathetic judges permit cruder rhetorical standards, and conscientious judges are confronted with confused precedent generally deferential to prosecutorial bombast.

In the absence of a clear showing to the contrary, there is a strong appellate presumption that judicial actions at the trial stage-sustaining defense counsel's objections, instructing the jury to disregard a prosecutor's rhetoric-are sufficient to cure any possibility of prejudicial error. ${ }^{176}$ But notions of the required measure of judicial cure vary widely. In many states, essentially unhelpful responses by the judge-cLet's move along," "This is just argument," "Stay within the record, counsel"-frequently are held sufficiently curative. ${ }^{177}$ Similarly, merely sustaining objections to

176 People v. Farrar, 36 Mich. App. 294, 299, 193 N.W.2d 363, 366 (1971). Many jurisdictions combine a virtually irrebuttable presumption of prejudice with supervisory considerations to require reversal where prosecutors make racially inflammatory appeals or predictions about defendant's future conduct, the threat to jurors' families, or the breakdown in society that would result from acquittal. See cases cited notes 49-50, 52-65, 100 supra.

${ }_{175}$ State v. Durden, 264 S.C. 86, 91-92, 212 S.E.2d 587, 590 (1975); accord, State v. Ray, 600 S.W.2d 70, 73 (Mo. Ct. App. 1980); State v. Reynolds, 603 P.2d 1223, 1228 (Or. Ct. App. 1979); State v. Walton, 5 Wash. App. 150, 152, 486 P.2d 1118, 1120 (1971).

${ }_{178}$ See State v. Gonzales, 105 Ariz. 434, 437, 466 P.2d 388, 391 (1970); Commonwealth v. MacDonald, 368 Mass. 395, 402, 333 N.E.2d 189, 194 (1975); People v. Williams, 73 A.D.2d 525, 525-26, 422 N.Y.S.2d 405, 406 (1979); Mitchell v. State, 408 P.2d 566, 572 (Okla. Crim. App. 1965). See generally J. StziN, supra note 2, §\$ 90-93.

177 Kovash v. State, 519 P.2d 517, 521 (Okla. Crim. App. 1974) (appeal "to answer the 
highly inflammatory deterrence appeals, or striking the remarks, have been held adequate judicial responses. ${ }^{178}$ Other state courts require a stronger response by the judge, including rebuke and reprimand of the prosecutor and admonition of the jury in forceful terms concerning the impropriety of the appeal. ${ }^{179}$ By defining the qualifying characteristics of improper debate and outlining specific curative standards, these states ensure respect for the rules of argument and avoid needless appellate review.

The trial judge also can help curb abuses that result from the various state preservation doctrines. Failure by defense counsel to object at the time of improper argument frequently is held to constitute a waiver, preventing the defendant from seeking appellate review based on admission of the prosecutor's remarks. ${ }^{180}$ The required degree of persistence to preserve rhetorical error, and the "hypertechnicality" of procedual steps that must be observed, ${ }^{181}$

public's cry" for conviction was sufficiently cured by judge's remark that jurors should consider evidence "and not respond to anything else that the public may be asking for"), cert. denied, 419 U.S. 830 (1974); see Crump, supra note 1, at 537 n. 221 (Texas cases).

${ }^{173}$ E.g., Wideman v. State, 339 So. 2d 1378, 1382 (Miss. 1976) (sustaining objection renders harmless the argument that defendant will rape again); Holifield v. State, 275 So. 2d 851, 856 (Miss. 1973) (sustaining objection sufficient to cure error in arguing that "next time it might be your house that is burglarized"), cert. dismissed, 414 U.S. 990 (1973); State v. Wilborn, 525 S.W.2d 87, 96 (Mo. Ct. App. 1975) (striking crime-in-the-streets rhetoric suffcient to cure prejudice).

${ }^{170}$ See Ailer v. State, 114 So. 2d 348, 351-52 (Fla. Dist. Ct. App. 1959) (trial judge must "so affirmatively rebuke" the prosecutor as to impress jurors with the "gross impropriety" of the appeal); State v. Hammonds, 290 N.C. 1, 11-13, 224 S.E.2d 595, 603-04 (1976). See generally J. STEIN, supra note 2, \$§ 90-91.

180 E.g., State v. Gonzales, 105 Ariz. 434, 437, 466 P.2d 388, 391 (1970) (if defendant acquitted and "somebody comes along and kills you," prosecutor will tell jurors' survivors that " 'we have got kind hearts. We don't prosecute anybody.' "); State v. Hayes, 364 So. 2d 923, 925-26 (La. 1978) (failure to object precluded reversal for prejudicial argument that "[y]ou've got a pusher, a big pusher, and you have an opportunity to do something about it and I pray that you do"); State v. Huson, 73 Wash. 2d 660, 662-64, 440 P.2d 192, 195 (1968) (failure to object constituted waiver with regard to statement that, if defendant acquitted, jurors "are going to be responsible for many, many killings of innocent people"), cert. denied, 393 U.S. 1096 (1969).

${ }^{181}$ See, e.g., Crump, supra note 1. Crump outlines the procedural maze for preservation in Texas:

1. First, you must make an objection. . . . The objection must be made at the first opportunity. . . . 2. Your objection must be done with specificity. . . . You cannot just say: "I object, Your Honor." . . . 5. You must get a ruling from the trial court. Overruled or sustained. 6 . If your objection is sustained, you must then get a ruling from the trial court to instruct the jury to disregard. 7. You must then make motion to strike from the Record. 8. You must then move for a mistrial. 9. You must then object and except for failure to grant your motion for mistrial. 10. If your objection is overruled, you must then XXXXXXXobject and except to the Judge's ruling. 11. You must be prepared to later renew your objection, whether it is sustained or not, when the State makes the second pass. 
vary substantially from state to state. These preservation doctrines often require Herculean diligence on the part of defense counsel, and force him to appear to be obstructionist, annoying both judge and jury, in order to enforce a client's rights. ${ }^{182}$ They also presuppose a standard of rhetoric to which defense counsel can point in objection. By hampering effective defense responses, the lack of clear standards perpetuates rhetorical abuse. Several states, in relaxing the requirements for raising and preserving objections to prosecutorial abuse, have expanded the judge's duty to act sua sponte to "check and control" forbidden deterrence appeals. ${ }^{183}$

\section{Right-of-Reply Doctrine}

Where the defendant admits committing the acts that constitute the crime but defends himself by asking for sympathy and leniency because of the trivial nature of the crime or the political unpopularity of the law, it would be unwarranted to forbid the prosecutor from responding by discussing the purposes of the law, the seriousness of the crime, and the need for evenhanded verdicts. Relevant responses can be accommodated under the traditional "right-of-reply" doctrine. ${ }^{184}$ Where the defendant bases his defense upon policy grounds, many opinions have recognized that although

Id. at 537 n.221 (quoting speech by Marvin Teague, Houston Bar Ass'n, Mar. 15, 1974).

${ }^{182}$ E.g., Jones v. State, 437 S.W.2d 822, 824 (Tex. Crim. App. 1969) ("it's getting pretty close to home, as you can see him [defense counsel] jumping up every couple of minutes here"; trial judge instructed jury to disregard the remarks).

These preservation requirements place defense counsel in a cruel dilemma, forcing him either to forgo objection or underscore the prosecutor's appeal. Judge Frank maintained that "a prosecutor ought not deliberately and repeatedly . . . put defendant's lawyer in such an awkward dilemma." United States v. Grayson, 166 F.2d 863, 871 (2d Cir. 1948) (Frank, J., concurring). See generally Singer, supra note 1, at 242-46.

${ }^{183}$ See People v. Farrar, 36 Mich. App. 294, 299 n.6, 193 N.W.2d 363, 366 n.6 (1971); People v. Plautz, 28 Mich. App. 621, 623, 184 N.W.2d 761, 762 (1970). While objection should not be required for preservation of error, failure to object should be one strong factor in considering whether the error was harmless. E.g., People v. Love, 91 Mich. App. 495, 504, 283 N.W.2d 781, 785 (1979); City of St. Paul v. Jackson, 293 Minn. 505, 506-07, 198 N.W.2d 275, 277 (1972). Note also the Supreme Court's clear statement in its supervisory role in a civil case, New York Cent. R.R. v. Johnson, 279 U.S. 310, 318-19 (1929):

The public interest requires that the court of its own motion . . . protect suitors in their right to a verdict uninfluenced by the appeals of counsel to passion or prejudice. . . . Where such paramount considerations are involved, the failure of counsel to particularize an exception will not preclude this Court from correcting the error.

18s See generally J. STEIN, supra note 2, § 88; see also ABA STANDARDS, supra note 7, commentary to $\$ 5.8$ (d) ("a prosecutor may be justified in making a reply to an argument of defense counsel which may not have been proper if made without provocation"). 
the prosecutor's subsequent rhetoric would otherwise be impermissible, it was invited by improper defense assertions. ${ }^{185}$ However, many courts have used the right-of-reply doctrine as a rule of unclean hands that estops the defendant to object to prosecutorial improprieties altogether, rather than as a limited corrective. ${ }^{180}$ This results in a virtually unrestrained prosecutorial license, sanctioning rhetorical appeals that go far beyond a mere response to the language employed by defense counsel. ${ }^{187}$

\section{CONCLUSION}

The present level of judicial tolerance for deterrence appeals by prosecutors varies significantly from state to state, ranging from categorical strictures to doctrines routinely sanctioning shocking appeals to fear and loathing. This comment has argued that the former course is the correct one: deterrence appeals should be prohibited.

${ }^{18 s}$ E.g., State v. Sercovich, 246 La. 503, 522, 165 So. 2d 301, 307 (1964) (defendant admitted sale of marijuana and made sympathy his main plea; prosecutor permitted to argue the social consequences of illicit narcotics); People v. Williams, 58 A.D.2d 943, 944-45, 397 N.Y.S.2d 444, 445-46 (1977) (prosecutor's remarks that "the South Bronx is a jungle, an absolute jungle," and that "if you are going to find him not guilty, you're going to call those cops liars and it was a frame" were fair reply to defense attorney's theory that his client was "framed" without any evidence in support of that theory); State v. Watson, 20 Ohio App. 2d 115, 124-25, 252 N.E.2d 305, 313 (1969) (prosecutor's inflammatory remarks about black militant excused because defendant had argued that state was attempting to conduct political trial based on innuendo); Carnathon v. State, 478 S.W.2d 490, 493-494 (Tex. Crim. App.) (discussion of legislative purpose for probation laws prompted by defense counsel), cert. denied, 409 U.S. 866 (1972).

186 See J. Stzin, supra note 2, § 88; Alschuler, supra note 1, at 658; Crump, supra note 1 , at 531-33.

187 See, e.g., State v. Karstetter, 110 Ariz. 539, 543-44, 521 P.2d 626, 630-31 (1974) (defense discussion of reasonable doubt standard for insanity justified prosecutor's remarks that the defendant would go free if found not guilty by reason of insanity); Minafee v. State, 482 S.W.2d 273, 275-76 (Tex. Crim. App. 1972) (defense argument that victim's testimony was contradictory justified reply that acquittal will mean "that it's all right to go out and find you an old man and one that can't remember and one that will get confused, and rob him").

Professor Alschuler suggests that the doctrine be reformulated so that the question is not "whether the prosecutor was 'provoked,' but whether the prosecutor's action was reasonably designed to remedy the wrong perpetrated by the defense." Alschuler, supra note 1, at 658.

In any event, the import of the right-of-reply doctrine is easily exaggerated; defense counsel are forbidden to argue social policy, and trial judges routinely prevent such appeals sua sponte. See ABA STANDARDs, supra note 7, commentary to $\$ 5.8$ (d) ("The better solution [than right of reply] lies in having advocates adequately instructed as to the limits of proper argument and trial judges willing to enforce fair rules as to such limits."). 
To give effect to this conclusion in the courtroom, the "fearless administration" doctrine must be discarded, and the improper application of the harmless error rule must be curtailed. The states should announce clear standards to govern prosecutorial rhetoric, and these standards should be vigorously enforced by trial judges so as to conserve resources at the appellate level. Until such standards are employed, the prevalence of prejudicial deterrence rhetoric will remain a compelling example of how our standards of criminal procedure are "the measures by which the quality of our civilization may be judged."188

Charles G. Curtis Jr. 